\title{
Colydiine genera (Coleoptera: Zopheridae: Colydiinae) of the new World: A Key and Nomenclatural Acts 30 Years in the Making
}

\author{
Authors: Michael A. Ivie, Nathan P. Lord, Ian A. \\ Foley, and S. Adam Slipinski
}

This is a postprint of an article that originally appeared in Coleopterists Bulletin on December 18, 2016. https://dx.doi.org/10.1649/0010-065X-70.4.755

Ivie, Michael A. , , Ian A. Foley, and S. Adam Slipinski. "Colydiine genera (Coleoptera: Zopheridae: Colydiinae) of the new World: A Key and Nomenclatural Acts 30 Years in the Making." Coleopterists Bulletin 70, no. 4 (April 2017): 755-788. DOI: 10.1649/0010-065X-70.4.755. 


\title{
Colydine Genera (Coleoptera: Zopheridae: Colydinae) of the New World: A Key and Nomenclatural Acts 30 Years in the Making
}

\author{
Michael A. Ivie \\ Montana Entomology Collection, Marsh Labs, Room 50 \\ Montana State University \\ Bozeman, MT 59717, U.S.A. \\ mivie@montana.edu \\ NATHAN P. LoRD \\ Department of Biological and Environmental Sciences \\ Georgia College and State University \\ Milledgeville, GA 31061, U.S.A. \\ IAN A. FolEY \\ Montana Department of Agriculture \\ Helena, MT 59601, U.S.A. \\ AND \\ S. ADAM ŚLIPIŃSKI \\ CSIRO Ecosystem Sciences \\ Australian National Insect Collection \\ GPO Box 1700, Canberra, ACT 2601, AUSTRALIA
}

\begin{abstract}
A brief review of the classification history of the subfamily Colydiinae is provided, followed by a provisional diagnosis for the group. The 47 genera of New World Colydiinae (Colydiidae auctorum) are reviewed, with an illustrated key to genera, a representative habitus of each genus, a list of all 305 described species currently considered valid, each placed into the appropriate recognized genus, with full citations for each. Numerous nomenclatural changes are noted. Opostirus Kirsch is transferred to the Tenebrionidae: Eudysantina, new placement. The Adimerini Sharp 1894 are synonymized with Synchitini Erichson, 1845, new synonymy. In the Acropini, Lemmis Pascoe, $1860=$ Acropis Burmeister, 1840, new synonymy, with Acropis caelatus (Pascoe, 1860), new combination and Acropis tuberosus (Grouvelle, 1896), new combination. Acropis fryi Pascoe, $1860=$ Acropis tuberculifera Burmeister, 1840, new synonymy and Acropis incensa Pascoe, $1860=$ Acropis aspera Pascoe, 1860, new synonymy. In the Synchitini, Anisopaulax Reitter, 1877 = Lasconotus Erichson, 1845, new synonymy, with Lasconotus brucki (Reitter, 1877), new combination. Pristoderus brasiliensis (Grouvelle, 1896), new combination follows synonymization of Ulonotus Erichson with Pristoderus. Eucicones Sharp, 1894 = Catolaemus Sharp, 1894 = Cacotarphius Sharp, 1894, new synonymies, with Eucicones minutus (Sharp, 1894), new combination and Eucicones compressus (Sharp, 1894), new combination. Reylus Ivie, Lord, Foley, and Ślipiński is a new replacement name for Erylus Dajoz, 1969 [not Erylus Gray, 1867 (Porifera)]. Eulachus Erichson, 1845 = Anarmostes Pascoe, 1860, new synonymy, with Anarmostes costatus (Erichson, 1845), new combination, Bitoma quinquecarinata (Chevrolat, 1864), new combination, and Bitoma semifuliginosa Chevrolat, 1864), new combination. Hystricones Sharp, $1894=$ Paryphus Erichson, 1845, new synonymy, with Paryphus armatus (Sharp, 1894), new combination and the following species moved to Colobicones Grouvelle, 1918: Colobicones vagans (Arrow, 1927), new combination; Colobicones hirtus (Ślipiński, 1985), new combination; and Colobicones papuanus (Ślipiński, 1985), new combination. Labrotrichus Sharp, $1894=$ Neotrichus Sharp, 1885, new synonymy, with Neotrichus aberrans (Sharp), new combination and Neotrichus verrucatus (Hinton, 1935), new combination. Microsicus Sharp, 1894 = Synchita Hellwig in Schneider, 1792, new synonymy, resulting in changes for the Japanese species Synchita constricta (Aoki, 2012), new combination and Synchita parvula Guérin-Méneville, 1844, return to a previous combination. Synchita grouvellei Ivie, Lord, Foley, and Ślipiński, new replacement name is proposed for Microsicus minimus Grouvelle, 1898 [not Sharp, 1885]. The earlier synonymization of Cicones Curtis, 1827 with Synchita results in Synchita africana (Grouvelle, 1905), new combination, Synchita amoena (Fairmaire, 1850), new combination, Synchita colorata (Motschulsky, 1863), new combination, Synchita compacta (Grouvelle, 1918), new combination, Synchita eichelbaumi (Grouvelle, 1914), new combination, Synchita lata (Grouvelle, 1919), new combination, Synchita madagascariensis (Grouvelle, 1896), new combination, Synchita minor (Pope, 1954) new combination, Synchita minuta (Sharp, 1885) new combination, Synchita oblonga (Sharp, 1885), new combination, Synchita picta (Erichson, 1845), new combination, Synchita scotti (Grouvelle, 1918), new combination, and Synchita squamosa (Grouvelle, 1896), new combination. Synchita lecontei Ivie, Lord, Foley, and Ślipiński, new replacement name is proposed for Synchita variegata LeConte, 1858 [not Hellwig in Schneider, 1792]. The species formerly placed in Catolaemus belong in Synchita, resulting in Synchita
\end{abstract}


exilis (Grouvelle, 1898), new combination and Synchita multimaculata (Grouvelle, 1902), new combination. Cicones bitomoides Sharp, 1885, Cicones hayashii Sasaji, 1971, Cicones niveus Sharp, 1885, Cicones oculatus Sharp, 1885 , Cicones rufosignatus Sasaji, 1984, and Cicones variegatus (Hellwig in Schneider, 1792) are returned to Synchita as returned to previous combinations. Synchita hirsuta Aoki, 2008 is also returned to original combination from Microsicus. Pseudotaphrus Stephan, 1989 [not Cossmann, 1888 (Mollusca: Rissoiidae)], including the preoccupied replacement name Stephaniolus Ivie, Ślipiński, and Węgrzynowicz, 2002 = Coxelus Dejean, 1821, new synonymy, with Coxelus longus (Stephan, 1989), new combination. Zanclea Pascoe, 1863 [not Gegenbaur, 1856 (Cnidaria: Hydrozoa) = Aneumesa Sharp, 1894 = Holopleuridia Reitter, 1876, with Holopleuridia atomaria (Sharp, 1894), new combination, Holopleuridia costata (Sharp, 1894), new combination, and Holopleuridia testudinea (Pascoe, 1863), new combination. Other individual changes in generic membership are Asynchita panamensis (Sharp, 1894), new combination (from Synchita); Endeitoma rugulosa (Guérin-Méneville, 1844), new combination (from Asynchita Sharp, 1894, originally Synchita); Ethelema nigrogrisea (Grouvelle, 1914), new combination (from Lemmis); Paha mexicana (Hinton, 1935), new combination (from Namunaria); Paha mimetes (Sharp, 1894), new combination (from Synchita); Notocoxelus sylvaticus (Philippi in Philippi and Philippi, 1864), new combination (from Coxelus); Plagiope cubana (Zayas, 1988), new combination (from Ethelema Pascoe, 1860); Plagiope denticulata (Grouvelle, 1898), new combination (from Lemmis); Plagiope lherminieri (Grouvelle, 1902), new combination (from Lemmis); Pristoderus porteri (Brèthes, 1925), new combination (from Endophloeus Erichson, 1845); Pristoderus sharpi (Reitter, 1877), new combination (from Endophloeus); and Synchita pauxilla (Pascoe, 1863), new combination (from Bitoma Herbst). Lastly, Endestes sculpturatus Sharp, 1894 = Endestes incilis Pascoe, 1863, new synonymy.

Key Words: cylindrical bark beetles, taxonomy, new synonymies, new combinations, new replacement names

DOI.org/10.1649/0010-065X-70.4.755

zoobank.org/urn:1sid:zoobank.org:pub:6BD80DAE-59DD-41C9-A998-795232B0D010

Normally, the first thing to do in a paper of this type is to define the taxon under study. In this case, this is not a simple matter. The Colydiinae, the rump of the group known previous to 1999 as Colydiidae (Ślipiński and Lawrence 1999), have had a tortured nomenclatural and definitional history, increasingly stabilized with the removal of extraneous elements over the last 40 years (Ivie and Ślipiński 1990; Ślipiński and Lawrence 1999). The remainder's status as the sister-group of the Zopherinae in the redefined Zopheridae was formally proposed by Ślipiński and Lawrence (1999). This relationship, as well as the monophyly of the colydiines themselves, remains weakly supported (Ślipiński and Lawrence 1999), a possible result of a very limited taxon sampling (eight genera of five tribes) of the $c a .140$ recognized genera of colydiines placed in nine tribes, and especially by the limited selection of out-groups (Ivie 2002). This relationship of monophyly has not been recovered in some molecular analyses (i.e., Hunt et al. 2007; McKenna et al. 2015; K. Kanda, in litt.) but has been recovered (with the addition of the Trictenotomidae) in one subsequent morphological analysis (Lawrence et al. 2011). All of these studies are also severely limited by weak taxon sampling.

The unique synapomorphies recovered among four analyses reported to support the monophyly of the broad Zopheridae in Ślipiński and Lawrence (1999: figs. 259-262) are: (1) antennal insertions concealed (two of four analyses, only with restricted out-groups); (12) maxillary palpomere 2 less than $1.5 \mathrm{X}$ as long as 1 (all four analyses); (30) mesocoxal cavities closed laterally (all four analyses); and (39) aedeagus with tegmen dorsal (all four analyses). Less support was provided by: (21) prosternal process parallel-sided or slightly and gradually expanded apically; (36) no connate ventrites; (48) larval cardo undivided; and (52) larval hypopharyngeal sclerome consisting of a flat plate or elevated carina. There are a variety of problems with these characters as a basis for supporting monophyly for the Colydiinae + Zopherinae. Character 1 is only informative when the out-group is reduced to a group lacking the state (Ślipiński and Lawrence 1999: figs. 261, 262 ), and likely to be plesiomorphic and/or convergent. Concealed antennal insertions occur in 21 other families with tenebrionoid aedeagi (hereafter referred to as "tenebrionoid") (Lawrence et al. 1999), 20 of which were not included in the broader out-groups.

Although Character 12 is coded the same for all zopherines and colydiines except Rhagodera Mannerheim, it is in fact inconsistent within the Colydiinae, as maxillary palpomere 1 is more than $1.5 \mathrm{X}$ the length of 2 in Acropis Burmeister, Monoedus Horn, Rhagodera, and others. Such ratio characters, while useful for taxonomic purposes, are notoriously hard to homologize. Character 30, the closed mesocoxal cavities, also occurs in at least nine other tenebrionoid families, eight of which were not included in the out-group 
(Lawrence et al. 1999). Character 39 is scored (Ślipiński and Lawrence 1999: table 1) as having an inverted aedeagus with the tegmen ventral in Nematidium Erichson, Aulonium Erichson, Pseudendestes Lawrence, Todima Grouvelle, Pristoderus Hope, Namunaria Reitter, and Rhagodera, leaving only Bitoma Herbst among the taxa sampled with a normal dorsal tegmen. However, this is mis-scored for at least Nematidium and Namunaria, which have a dorsal tegmen, and the character varies within the Synchitini (ventral in Mamakius Pope and Denophoelus Stephan, dorsal in Paxillobitoma Lord and Ivie, Endeitoma Sharp, Globotrichus Lord and Ivie, etc., while both states occur in Bitoma). Characters 48 and 52 were not known for a major portion of the in-group and out-group taxa. The undivided cardo occurs in a dozen other tenebrionoid families and many more outside the superfamily, while 52 is variable both within the Colydiinae (Lawrence 1991) and Zopherinae (Ślipiński and Lawrence 1999: table 1).

Therefore, although at first glance Ślipiński and Lawrence's (1999) analyses look strong for supporting the inclusion of the Colydiidae in the Zopheridae, as they pointed out in their paper, the relationship remains tentative, and upon detailed study, the level of support was possibly dependent on limited selective choice of in-group and outgroup taxa, as well as issues of scoring. Thus, the clustering of colydiines and zopherines could easily be the result of not including intervening tenebrionoid groups, such as possibly the Synchroidae, Melandryidae, Trictenotomidae, and Tetratomidae. The analysis by McKenna et al. (2015) recovered most of the Zopheridae sensu lato together, but did not recover a colydiinezopherine sister-group, again with a very limited in-group sample, and part of the zopherines were excluded from that clade altogether. A robust test of this relationship is underway by one of us (NPL) using both molecular and morphological data from a large sampling of genera and species.

Moving to the colydiines themselves, unique morphological synapomorphies for the Colydiinae are simply lacking. The main support for the clade in Ślipiński and Lawrence (1999) is the 4-4-4 tarsal formula, which occurs not only repeatedly in the purported sister-group, but also in some 30 other tenebrionoid lineages in nine families (Lawrence et al. 1999). Monophyly of the colydiines has not been subsequently recovered in larger analyses (e.g., Lawrence et al. 2011; McKenna et al. 2015). As a result, a succinct diagnosis for the Colydiinae remains difficult to impossible. There is not even a diagnosis using only external characters that will consistently work beyond "tarsal formula 4-4-4 and lacking the synapomorphies of any other family."

Operationally, the group can be diagnosed in the New World by the following: tenebrionoid aedeagus; internally open procoxal cavities; concealed antennal insertions; clubbed antenna (ranging from weak to strong, usually involving $1-3$ segments, rarely gradual from $4^{\text {th }}$ or $5^{\text {th }}$ ); closed mesocoxal cavities; tetramerous, pseudotrimerous, or trimerous tarsi; and abdomen with 0-3 connate sterna. This combination will distinguish colydiines from other beetles in the New World, with the exception of Pycnomerus Erichson/Pycnomeroides Broun (Zopherinae) and Berginus Erichson (Mycetophagidae). In all but one species (Phreatus immsi Pascoe) with fully developed metathoracic wings that have been studied (a vast minority), colydiines have a medial (= subcubital) fleck, while Pycnomerus/ Pycnomeroides do not. The functional usefulness of this as a diagnostic character is limited by the fact that a major portion of the genera and species of Colydiinae and species of Pycnomerus/ Pycnomeroides lack functional metathoracic wings. Male Pycnomerus/Pycnomeroides have a setose pit on the mentum, which is always lacking in Colydiines, with the exception of the western Palearctic genus Langelandia Aubé, an odd group of eyeless, 3-3-3 tarsal formula species, whose placement requires further study (R. Schuh, in litt.). Wingless female Pycnomerus/Pycnomeroides have the distinctive habitus of the group. Ivie's (2002) keying of Pycnomerus with other Zopherinae on the basis of four connate sterna is an error since only three are connate in Pycnomerus, a state that also occurs in the Colydiinae. The other problem, Berginus, can be excluded by the impressed fronto-clypeal suture and paired basal impressions on the pronotum.

In the Old World, this diagnosis would exclude a few colydiines (Orthocerini, Rhopalocerini, and Aprostoma Guérin-Méneville-Gempylodini from Africa), which lack obviously clubbed antennae, and would again include Pycnomerus/ Pycnomeroides, as well as two genera of Latometini (Zopherinae from Australia) and Rhizonium Sharp (Tenebrionoidea incertae sedis, from New Zealand).

Excluding the Pycnomerini (now Zopherinae), the remaining Colydiinae have been divided into nine tribes since Ślipiński and Burakowski (1988), although every discussion of the tribes has repeated the doubtful validity of most of them (Ślipiński and Burakowski 1988; Ślipiński and Lawrence 1997, 1999, 2010; Węgrzynowicz 1999; Ivie 2002). We have herein reduced the number of tribes by the synonymy of the Adimerini Sharp with the Synchitini Erichson. The only unique character in the Adimerini is the 
unarmed lacinia, which remains unstudied in a majority of synchitine genera, and hardly seems valid for supporting a small tribe in the absence of any synapomorphy for the synchitines. The purporting that the larvae of Monoedus feed on living plant tissue as a characteristic unique to the tribe (Ślipiński and Burakowski 1988) is a misunderstanding, as the larvae feed on dead plant material and are probably fungivorous. The adults may graze on surface fungi on dead or dying plants, where they can be taken in numbers. Other tribes, especially Nematidiini and Gempylodini, are only slightly better supported, but we will avoid further consolidation until phylogenetic information being developed by one of us (NPL) is available. Thus, the New World genera are herein placed in six of the eight currently recognized tribes.

Within the group as it is currently defined, the taxonomy is difficult, to say the least. No generic key has ever been published for the world fauna, nor for the Neotropics, where no regional treatment has been done since Sharp (1894a, b), which was limited to Central America (including Mexico). Other regions fare better, with the Palearctic (Dajoz 1977), Japan (Aoki 2012a), Madagascar (Dajoz 1980a), Australo-Pacific (Ślipiński and Lawrence 1997), Africa (Pope 1961) and North America north of Mexico (Ivie 2002; Lord et al. 2011) having workable generic keys. With the completion of this key, only the Oriental region remains without a working generic system.

Rather than provide a key restricted to the Neotropical genera, we have chosen to treat the entire New World fauna as a whole (including Hawaii), to better allow definition of the groups. All described New World taxa considered members of the Colydiinae are placed in the checklist that follows the key. Only synonymies proposed since Hetschko (1930) or not included in a selection of major works (Hetschko 1930; Stephan 1989; Ivie and Ślipiński 1990; Ślipiński and Lawrence 1997; Węgrzynowicz 1999; Ivie 2002; Lord and Leschen 2014) are included, and those papers should be consulted for full information on available synonyms. Numerous new synonymies and generic transfers were needed to make the genera at least typologically coherent. These changes are detailed in the discussions below and summarized in the checklist.

New genera required to allow placement of all New World species known to us are described in an accompanying paper (Lord and Ivie 2016), which has precedence over this one for nomenclatural acts. No pretense of a fully monophyletic classification is made, but we feel this arrangement provides a good starting point for future phylogenetic exploration. No phylogenetic study of the subfamily has ever been undertaken, and we fully expect several of the genera to fall to problems of monophyly in the future. Within the Synchitini, the genus Bitoma in particular is almost certainly rendered paraphyletic by other genera, as is Synchita Hellwig in Schneider. However, we will retain most of the current typological generic concepts for the sake of stability until well-constructed phylogenetic analyses on a world scale can be used to reclassify the entire group on monophyletic principles.

One genus, Phreatus Pascoe, is included in the key but is not placed in a tribe. Rather, it is left as incertae sedis in the Colydiinae. Its membership in this group is seemingly solid, but it does not fit in any other obvious place (Ivie and Lord, unpublished data).

Of the 47 genera recognized herein, four of them are limited to the Nearctic and 21 to the Neotropics (Table 1). Twenty-nine of these genera are New World endemics, six are more-or-less cosmopolitan, and two are Old World endemics that have been introduced to the New World via trade. Of the remainder, four are shared only with the Palearctic, four with the Australasian Region, and one is Hawaiian/Australasian. Two (or three) are southern temperate groups shared between Chile and New Zealand/Australia. The intergeneric relationships are beyond the scope of this paper and will not be discussed further.

The group is fertile ground for discoveries. The 305 species recognized here are but a drop in the bucket. Based upon groups under revision, Acropini (by Foley), Aulonium (by Ślipiński), Monoedus (by Foley, Ślipiński, and Ivie), and Phloeonemus Erichson (by Ivie and Ślipiński), there may be 2-5 times as many undescribed species as described species of New World colydiines. Several groups suitable for student projects are among the New World genera.

\section{Nomenclatural ACtS}

This project is a compilation of work started by SAS in the late 1970 s and joined by MAI in the mid-1980s. After the birth and maturation of the other two coauthors (IAF and NPL), they joined the struggle in the early $21^{\text {st }}$ century after discovering the long dormant manuscript and kicked life back into the project. During the ensuing decades, large numbers of required nomenclatural acts have piled up in all of our notes. Some have been published along the way (Ivie and Ślipiński 1990; Ślipiński and Lawrence 1997; Ivie 2002; Lord and Leschen 2014), but many remain unrecorded. The need for these changes was a continuing hindrance to completion of the key. We use this opportunity to report all of the remaining issues 
Table 1. World distribution of Colydiinae genera occurring in the New World. Black = natural occurrence; Gray $=$ introductions. NA $=$ Nearctic $; \mathrm{NT}=$ Neotropical; $\mathrm{HI}=$ Hawaiian; $\mathrm{PA}=$ Palearctic; $\mathrm{AF}=$ Afrotropical; $\mathrm{OR}=$ Oriental; $\mathrm{AU}=$ Australasian .

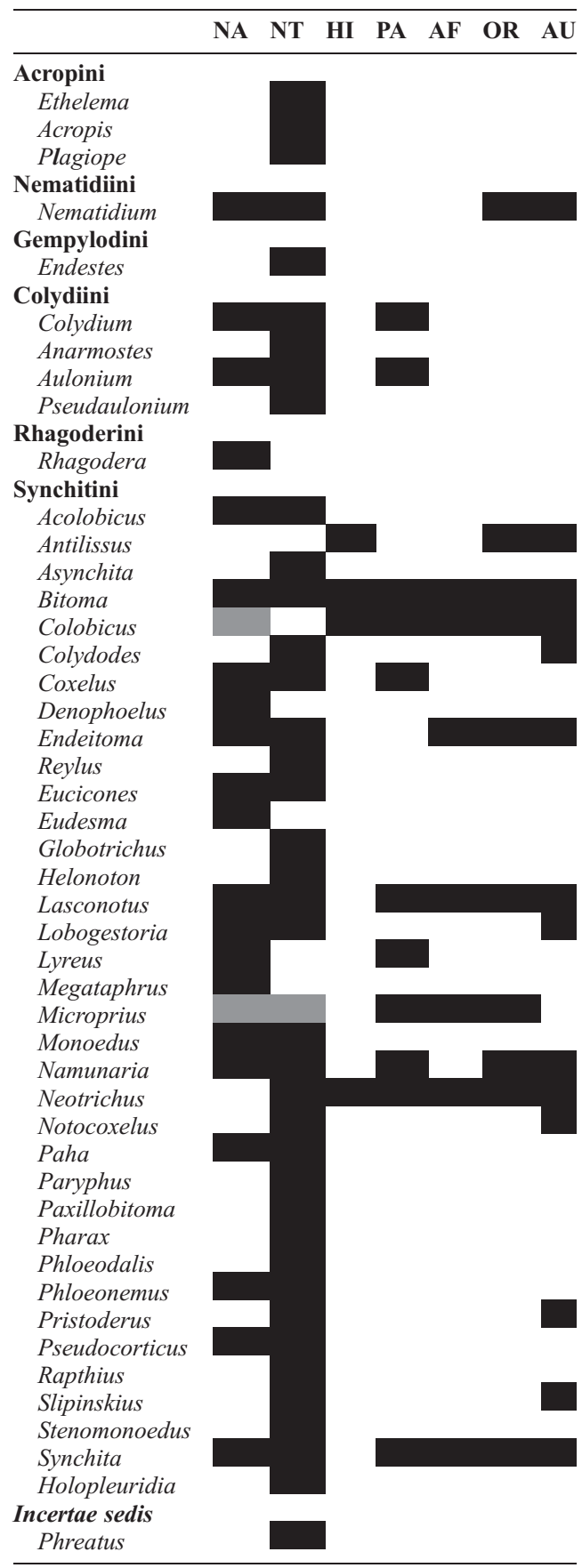

so as to provide the best synopsis of our collective knowledge of this group as is possible at this time. A companion paper to this one (Lord and Ivie 2016) validates several new generic and specific names and takes priority over this paper under the Principle of First Reviser (Art. 24.2.2., ICZN 1999).

\section{Family Transfer}

Opostirus Kirsch, 1865 was placed in the Synchitini, incertae sedis, by Ivie and Ślipiński (1990), who reported the type to be "lost?" from the Staatliches Museum für Tierkunde in Dresden. The curator, Dr. Klaus-Dieter Klass, confirms it has not been found since. No colydiine known to us fits the rather inadequate description, but the details provided do fit specimens of Ozolais Pascoe, 1866 or a related genus in the Tenebrionidae. The details of the antennal club, the prothorax, the eye canthus and horn, and the double row of bumps on the tibia are exactly and uniquely applicable to that group. Therefore, Opostirus Kirsch (type species $O$. exsectus Kirsch by monotypy) is transferred to the Tenebrionidae: Tenebrioninae: Toxicini: Eudysantina, new placement.

\section{Tribal Synonymy}

The tribe Adimerini Sharp, 1894 is synonymized with Synchitini Erichson, 1845, new synonymy. This group is small, consisting of two highly modified genera - Monoedus Horn, 1882 and Stenomonoedus Heinze, 1954 - but no characters are known (in adults or larvae) that are not derivable from within the Synchitini. See the introduction for more information.

\section{New Generic and Specific Synonymies, Resolution of Homonymies, Replacement Names, New Combinations, Generic Transfers, and Correction of Missed Combinations}

\section{Acropini}

The genus Lemmis Pascoe, $1860=$ Acropis Burmeister, 1840, new synonymy, resulting in Acropis caelatus (Pascoe, 1860), new combination, and Acropis tuberosus (Grouvelle, 1896), new combination. The species Acropis fryi Pascoe, $1860=$ Acropis tuberculifera Burmeister, 1840, new synonymy, and Acropis incensa Pascoe, $1860=$ Acropis aspera Pascoe, 1860 , new synonymy.

\section{Synchitini}

Anisopaulax Reitter, 1877 = Lasconotus Reitter, 1845, new synonymy, resulting in Lasconotus brucki (Reitter, 1877), new combination. 
Pristoderus brasiliensis (Grouvelle, 1896), new combination results from Ślipiński and Lawrence's (1997) synonymization of Ulonotus Erichson with Pristoderus.

Eucicones Sharp, 1894 = Catolaemus Sharp, 1894 = Cacotarphius Sharp, 1894, new synonymies. Determining which of these names is the senior synonym is somewhat complicated as all were published in the same part of Volume 16 of the Biologia Centrali-Americana [Coleoptera II (1)], however, they are not equal in priority in the sense of the ICZN. The Biologia CentraliAmericana, as in virtually all books, was printed in 16-page signatures, and in this case they were mailed (i.e., published) in parts. Each of the above names was printed in a different signatureEucicones was published in part CXVIII, signature 3M, mailed in October 1894; Catolaemus was in the same part (CXVIII), but in signature $3 \mathrm{~N}$, also mailed in October 1894; and Cacotarphius in part CXIX, signature 3P, mailed November 1894 (Lyal 2011). Thus, Cacotarphius is clearly a junior synonym to the other two names, but the remaining problem is ambiguous. We expect that part CXVIII was all mailed together, but although there is no evidence for this, it is possible signature $3 \mathrm{M}$ was mailed before $3 \mathrm{~N}$. So, we choose Eucicones as senior to Catolaemus by Principle of First Reviser (ICZN Art. 24.2.2), recognizing that future research may establish its priority by date of publication. These generic synonymies result in Eucicones minutus (Sharp, 1894b), new combination (from Catolaemus) and Eucicones compressus (Sharp, 1894b), new combination (from Cacotarphius).

Erylus Dajoz, 1969 is a junior homonym of Erylus Gray, 1867 (Porifera). Dajoz chose the name as an anagram of Lyreus Aubé, but unfortunately, of all possible anagrams of that name, he chose the only one that was preoccupied. Following the ICZN Code of Ethics, paragraph 3, we contacted Roger Dajoz via Dr. Thierry Deuve (in litt. to MAI, 21 December 2012) and received permission to replace this name. We do so with another anagram, Reylus, Ivie, Lord, Foley, and Ślipiński, new replacement name for Erylus Dajoz, 1969 (not Erylus Gray, 1867).

The status of Eulachus Erichson and Eulachus costatus Erichson is a problem. Erichson (1845) validly described both in his 1845 work (Ivie and Ślipiński 1990), but published a plate and its explication later. Hetschko (1930), Blackwelder (1945), and Ślipiński (1985) mistakenly considered the plate to be the validation of the species and misattributed the species on the plate to Thomson in Lacordaire (1854) (Ivie and Slipiński 1990) because, on the plate, the species was attributed to Thomson. In any case, the species illustrated is clearly a species of Anarmostes Pascoe, 1860, but these plates were published separate from the 1845 description and seem to have been seldom consulted. Further misdirection was because Erichson (1845) stated his species was from the West Indian islands, and Anarmostes is not known from the West Indies in the modern biogeographic sense. On the plate explication (Lacordaire 1854), this locality was changed to "Antilles." Thomson (1857) further discussed this species, added some descriptive remarks that strengthen its placement as an Anarmostes, and made it clear the Erichson and Thomson attributions referred to the same animal. Thomson (1857) corrected the locality to Cayenne, with Antilles listed with a "?". Cayenne is the capital of French Guiana and was an island at the time. As such, Cayenne was at that time considered a West Indian island in a political sense.

LeConte (1863) and those following him used Erichson's name for a group of North American species of narrow, cylindrical Bitoma. Chevrolat (1864) named two species in LeConte's sense, but indicated uncertainty about their proper placement in Eulachus.

Hetschko (1930) treated Eulachus as a valid genus, placed in his Colydiini, with the type species, E. costatus, misattributed to Thomson. He properly removed LeConte's concept of the genus to Bitoma, but left three other species (besides E. costatus) in Eulachus. Unfortunately, these three species also belong to LeConte's concept, not Erichson's.

Blackwelder (1945) followed Hetschko and used the genus in the sense of Erichson, placing it in the Colydiini and formally treating LeConte's concept as Bitoma, but continued to misattribute E. costatus to Thomson. He also continued to treat two Chevrolat species as members of this genus.

Eulachus was synonymized repeatedly with Bitoma, then removed from synonymy over the decades (Dajoz 1984a [into synonymy]; Ślipiński 1985 [into synonymy]; Stephan 1989 [into synonymy]; Ivie and Ślipiński 1990 [out of synonymy]; Ślipiński and Lawrence 1997 [into synonymy]; Ivie 2002 [into synonymy], and so on), but always using LeConte's concept of the genus, not Erichson's. At the time of the publication of our work, the genus was in the Synchitini as a junior synonym of Bitoma.

We here remove Eulachus Erichson and its type species Eulachus costatus to Anarmostes, new synonymy, resulting in Anarmostes costatus (Erichson), new combination. Finally, the two Chevrolat species that remained in Eulachus are moved, becoming Bitoma quinquecarinata (Chevrolat, 1864), new combination and Bitoma semifuliginosa (Chevrolat, 1864), new combination. 
Hystricones Sharp, 1894 = Paryphus Erichson, 1845 , new synonymy, resulting in Paryphus armatus (Sharp, 1894), new combination. Ślipiński and Lawrence (1997) indicated that Old World species of Hystricones are not congeneric with the type species (H. armatus Sharp, 1894) and should belong to Colobicones Grouvelle, 1918. A list of affected species was not given, and this was not noticed by Zoological Record. With our synonymization of Hystricones under Paryphus, these names are orphaned, so we provide the following new combinations: Colobicones vagans (Arrow, 1927), new combination; Colobicones hirtus (Ślipiński, 1985), new combination; and Colobicones papuanus (Ślipiński, 1985), new combination (all from Hystricones).

Labrotrichus Sharp, 1894 = Neotrichus Sharp, 1885, new synonymy, resulting in Neotrichus aberrans (Sharp, 1894), new combination and Neotrichus verrucatus (Hinton, 1935), new combination. Microsicus Sharp, 1894 = Synchita Hellwig in Schneider, 1792, new synonymy, resulting in Synchita parvula Guérin-Méneville, 1844, return to a previous combination. This move also renders Microsicus minimus Grouvelle, 1898 a junior secondary homonym of Cicones minimus Sharp, 1885. Synchita grouvellei Ivie, Lord, Foley, and Ślipiński, new replacement name is proposed for Microsicus minimus Grouvelle, 1898 [not Sharp, 1885].

Ślipiński and Lawrence 1997 synonymized Cicones Curtis, 1827 with Synchita. This synonymy was noted by Ślipiński and Schuh (2008), and the following Old World species have changes resulting from that move: Synchita africana (Grouvelle, 1905), new combination; Synchita amoena (Fairmaire, 1850), new combination; Synchita angustissima (Nakane, 1967), new combination; Synchita bitomoides (Sharp, 1885), new combination; Synchita bonina (Nakane, 1991), new combination; Synchita colorata (Motschulsky, 1863), new combination; Synchita compacta (Grouvelle, 1918), new combination; Synchita eichelbaumi (Grouvelle, 1914), new combination; Synchita hayashii (Sasaji, 1971), new combination; Synchita iranica (Dajoz, 1977), new combination; Synchita lata (Grouvelle, 1919), new combination; Synchita madagascariensis (Grouvelle, 1896), new combination; Synchita minima (Sharp, 1885), new combination; Synchita minor (Pope, 1954), new combination; Synchita minuta (Sharp, 1885), new combination; Synchita nivea (Sharp, 1885), new combination; Synchita oblonga (Sharp, 1885), new combination; Synchita oculata (Sharp, 1885), new combination; Synchita picta (Erichson, 1845), new combination; Synchita scotti (Grouvelle, 1918), new combination;
Synchita squamosa (Grouvelle, 1896), new combination; Synchita tokarensis (Nakane, 1967), new combination; Synchita undata (GuérinMéneville, 1844), new combination; and Synchita variegata (Hellwig in Schneider, 1792), new combination.

Synchita variegata LeConte, 1858 is a secondary junior homonym of Cicones variegatus (Hellwig in Schneider, 1792). Synchita lecontei Ivie, Lord, Foley, and Ślipiński, new replacement name is proposed for Synchita variegata LeConte, 1858 [not Hellwig in Schneider, 1792].

Aoki (2011, 2012a) placed several Japanese species originally described in Cicones in Microsicus, a genus that had not previously been used for Old World species. Most of these had already been placed in Synchita by Ślipiński and Schuh (2008) [cited by Aoki (2012a) as Löbl and Smetana]: Cicones bitomoides Sharp, 1885; Cicones hayashii Sasaji, 1971; Cicones niveus Sharp, 1885; Cicones oculatus Sharp, 1885; Cicones rufosignatus Sasaji, 1984; Cicones variegatus (Hellwig in Schneider, 1792) (misattributed by Aoki 2012a to LeConte). Because of the generic synonymy, these are now correctly placed back in Synchita, and all are returned to previous combinations. Synchita hirsuta Aoki, 2008 was placed in Microsicus by Aoki (2012a) and is also returned to previous combination. This species was missed by Zoological Record and Ślipiński and Schuh (2008). We note that Pseudosynchita hirsuta Pic, 1922, which is itself now a junior synonym of Synchita crenicollis Wollaston, 1867 (Ślipiński and Schuh 2008), would be a senior secondary homonym if recognized as valid, but we do not address this further here. Lastly, Microsicus constrictus Aoki, 2012 was described (Aoki 2012b) after Aoki (2012a), and is herein placed as Synchita constricta (Aoki, 2012), new combination. Although Catolaemus is synonymized with Eucicones, the following species formerly placed in Catolaemus belong in Synchita: Synchita exilis (Grouvelle, 1898), new combination; and Synchita multimaculata (Grouvelle, 1902), new combination.

Pseudotaphrus Stephan, 1989 [not Pseudotaphrus Cossmann, 1888 (Mollusca: Rissoiidae)], including the replacement name Stephaniolus Ivie, Ślipiński, and Węgrzynowicz, 2002 = Coxelus Dejean, 1821, new synonymy, resulting in Coxelus longus (Stephan, 1989), new combination.

Zanclea Pascoe, 1863 is a junior homonym of Zanclea Gegenbaur, 1856 (Cnidaria: Hydrozoa). We herein synonymize Aneumesa Sharp, 1894 and Holopleuridia Reitter, 1876 with the concept of Zanclea Pascoe. Under these circumstances, the genus is now known under the oldest synonym, Holopleuridia. This change requires the 
following changes: Holopleuridia atomaria (Sharp, 1894), new combination; Holopleuridia costata (Sharp, 1894), new combination; and Holopleuridia testudinea (Pascoe, 1863), new combination.

The following individual species are moved to different genera, which results in these changes: Asynchita panamensis (Sharp, 1894), new combination (from Synchita); Endeitoma rugulosa (Guérin-Méneville, 1844), new combination (from Asynchita Sharp 1894, originally Synchita); Ethelema nigrogrisea (Grouvelle, 1914), new combination (from Lemmis); Paha mexicana (Hinton, 1935), new combination (from Namunaria); Paha mimetes (Sharp, 1894), new combination (from Synchita); Notocoxelus sylvaticus (Philippi in Philippi and Philippi, 1864), new combination (from Coxelus); Plagiope cubana (Zayas, 1988), new combination (from Ethelema Pascoe, 1860); Plagiope denticulata (Grouvelle, 1898), new combination (from Lemmis); Plagiope lherminieri (Grouvelle, 1902), new combination (from Lemmis); Pristoderus porteri (Brèthes, 1925), new combination (from Endophloeus Erichson, 1845); Pristoderus sharpi (Reitter, 1877), new combination (from Endophloeus); and Synchita pauxilla (Pascoe, 1863), new combination (from Bitoma).

And lastly, this species synonym was discovered in the course of this project: Endestes sculpturatus Sharp, $1894=$ Endestes incilis Pascoe, 1863, new synonymy.

\section{Character Definitions}

Nomenclature of morphological structures follows Doyen (1966), Doyen and Lawrence (1979), Lawrence and Britton (1991), Ślipiński and Lawrence (1999), Lawrence et al. (2010), and Lawrence et al. (2011). The following are to further explain characters used in the key.

Surface Sculpture. A tubercle is defined as a rounded protuberance of the cuticle that bears a single inserted seta. This differs from a nodule, which refers to a large, rounded or teardrop-shaped elevation of an entire cuticular area, which may bear multiple setae and/or tubercles on the surface (see Foley and Ivie 2008).

Antennal Club. The antennal club (Fig. 1a-i) is here defined as the terminal antennomere plus those proximal that are expanded and bear specialized, setose sensory areas, usually at or near the apical angles. Historically, the number of antennomeres in the club and the form of the club have been important defining characters for colydiine genera. Unfortunately, this is not as simple as it seems. The base number of antennomeres in this group, as in beetles in general, is 11 . In the major- ity of colydiines, the last two of these are expanded into a distinct club (Fig. 1d-e). Occasionally, the ninth is also expanded, forming a 3-segmented club (Fig. 1f-h). This condition is characteristic of the common cosmopolitan genus Lasconotus and the South Temperate Pristoderus. However, in Lasconotus there are very rarely seen Neotropical species with only the last two antennal segments expanded, and members of the Australian genus Synagathis Carter and Zeck, 1937 have lost the $11^{\text {th }}$ antennomere, resulting in a 2 -segmented club comprised of antennomeres 9 and 10 (Ślipiński and Lawrence 1997). In virtually all of the genera characterized by 1 -segmented clubs, there appear to be only 10 antennomeres, often with at least some indication of a fusion line between 10 and 11 (Fig. 1a-c). The degree of distinctness between a 1- vs. 2-segmented club is thus sometimes difficult, even arbitrary. In those cases, reference in the key is given to a specific figure.

To determine the number of club segments in ambiguous cases, first establish the total number of antennomeres. If clearly 11 , no club segments are fused, thus simply count the expanded segments possessing sensory areas. Sometimes a smooth antennomere 9 is slightly widened, usually triangular, and leads into the club. This is not a club segment if it does not have the setose sensory areas. If there are fewer than 11 antennomeres, examine the club from the view of the broadest surface and look along the lateral margins for notches that indicate a division between antennomeres 10 and 11 . If there is a true articulation at these notches, then the club is considered 2-segmented. If a curved line is present, but without the ability to move the individual sections relative to one other, the club is considered 1-segmented. Another way to think about this: could one break off the $11^{\text {th }}$ antennomere separately from the $10^{\text {th }}$ ? Yes $=2$-segmented, No = 1-segmented.

Antennal Groove - Short vs Long. The antennal groove (Fig. 5a-c) is the delimited and depressed area ventrad the eye along the mesal margin, where the antenna rests when tucked under and alongside the head. This groove passes from below the antennal insertion, over the gena between the eye and mandibular base, and along the underside of the eye. The presence of the groove is defined by a distinct margin on the subgenal brace. In a short antennal groove, this defined area is limited to the area near the subgenal brace and does not extend behind the midpoint of the eye (Fig. 5b). In the case of a long antennal groove, it extends along and over the lateral edge of the postgena to reach past the mid-point of the eye (Fig. 5c). A shallow and unmargined depression is not an antennal groove (Fig. 5a). 

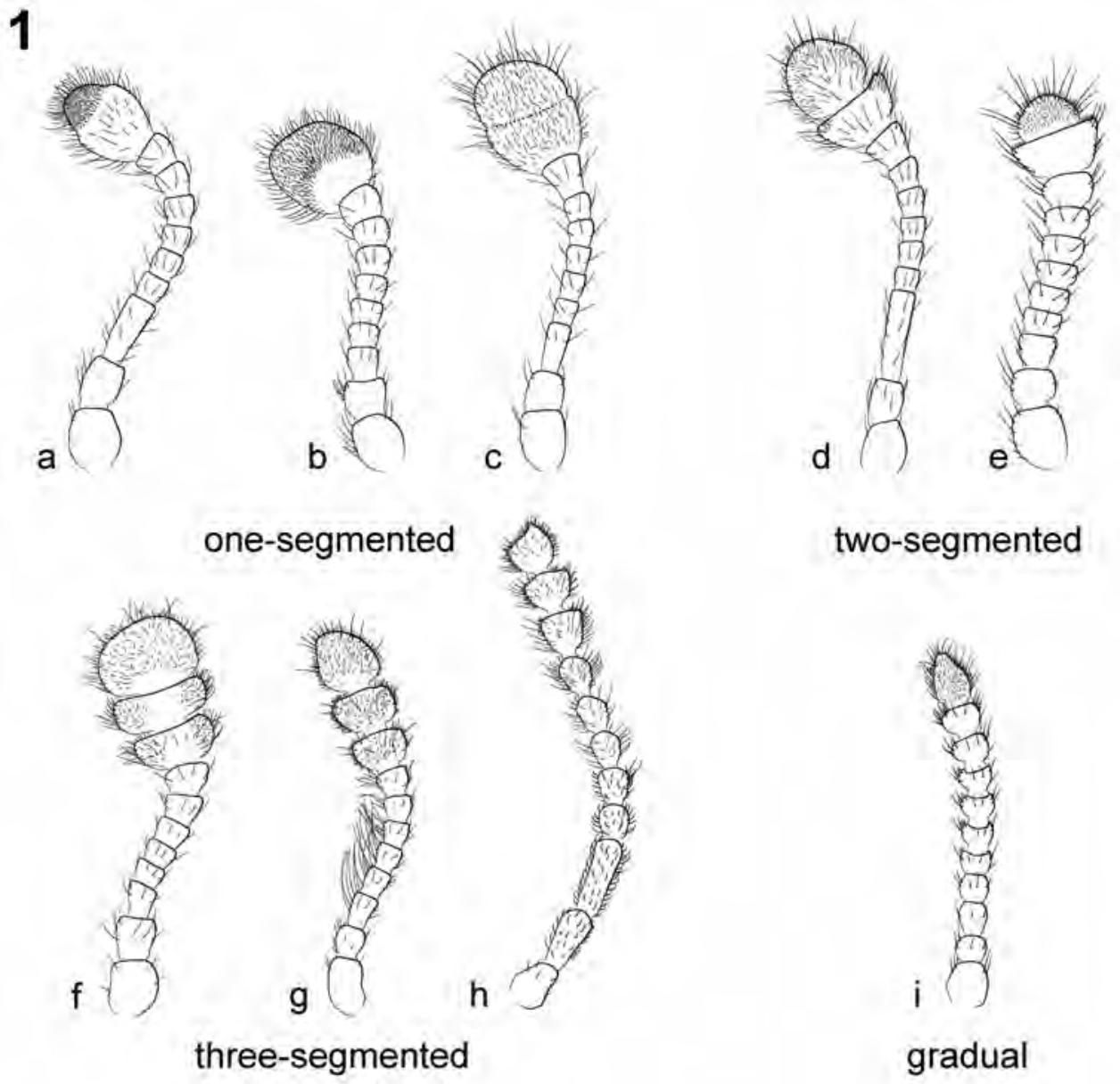

\section{two-segmented}

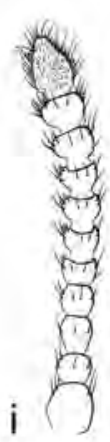

gradual

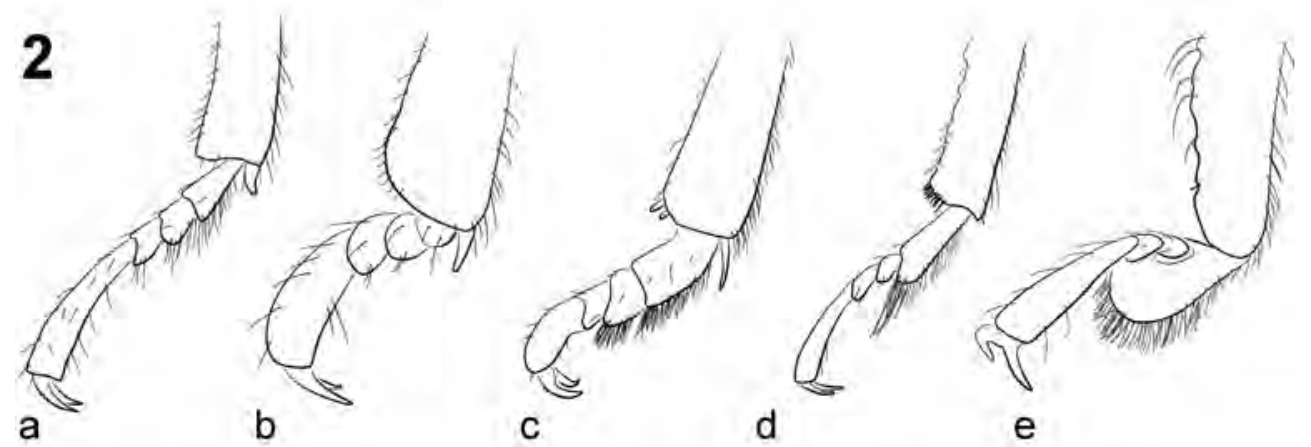

Figs. 1-2. Colydiinae anatomy. 1) Antennal types. Club 1-segmented: a) Endeitoma sp., b) Synchita sp., c) Acolobicus sp. Club 2-segmented: d) Colobicus sp., e) Lobogestoria sp. Club 3-segmented: f) Lasconotus sp., g) Colydium sp., h) Rhagodera sp. Club gradual: i) Endestes sp.; 2) Tarsi, prothoracic leg. a) Nematidium sp., b) Lobogestoria sp., c) Pseudaulonium sp., d) Acropis sp., e) Monoedus sp. 
Eye Longitudinal vs Vertical vs Round. Regarding the eye shape, the terms vertical, longitudinal, and round are in reference to the shape of the eye viewed from the side. "Longitudinal" is defined as the eye being significantly longer front-to-back than top-to-bottom (i.e., elongate anterior to posterior). "Vertical" is defined as the eye being significantly taller top-to-bottom (i.e., dorsal to ventral). "Round" is defined as the eye being neither vertical nor longitudinal (globular, suboval).

Labial Palpi. The presence of paired, segmented labial palpi is the basal condition for insects with chewing mouthparts. This is likewise the basal condition in colydiines. Interestingly, labial palpi are entirely lacking in a large, probably monophyletic, complex of South Temperate synchitines. This lineage is represented in the New World only by Pristoderus (see Ślipiński and Lawrence 1997, their record of Ablabus from Chile is here placed in Pristoderus). This character state can be difficult to interpret if the mouthparts are dirty. One additional caution in interpreting this character is that, in those species that lack labial palpi, the galea are enlarged and may be mistaken for the missing palpi. The expanded galea can be distinguished from a labial palp by the dense golden beard of setae on the apico-medial surface, which never occurs on the terminal palpomere.

Elytral Structures. The basic condition of the colydiines, as in most Coleoptera, is the presence of a scutellary striole and 11 punctate striae (Fig. 6), which along with the suture and lateral margin delimit intervals. The striae are usually depressed and the intervals raised. Striae may be absent or visible on only part of their length, and punctate or not. They are straight and complete in the basal condition, but may curve, merge apically with adjacent or distant striae, and/or become incomplete. The presence or absence of the scutellary striole is an important character in colydiines and consists of a short, curved set of punctures, or their remnant, in the scutellar angle of the elytra, adjacent to the scutellum, but not exceeding one-third of the total elytral length. The striae are then numbered from mesad to laterad. The scutellary striole is never included in the numbered series of striae. The interval mesad the scutellary striole is not included in the numbering of the remaining intervals, which are numbered from the suture to the lateral margin. The first interval (also called the sutural interval) is between the suture and the first stria (also called the sutural stria), interval 2 is between striae 1 and 2, and so on. Intervals are usually the site of ornamentation, including setae, carinae, and ridges. When an interval is more-or-less straight, complete, and uniformly and acutely raised, it is termed a carina (carinate). Roundtopped intervals are ridges. When the ridge is studded with raised sections that are not continuous (interrupted) and usually not sharply acute, they are termed tuberculate ridges. Apically, intervals curve, merge, and end in coordination with the striae. This may become so confused as to be impossible to decipher which raised piece belongs to what interval.

Abdominal Ventrite Characters. The shape of the ventrite I intercoxal process is used repeatedly to identify genera. In general, there are three main types: 1) a narrow process that has an acute apex (Fig. 4a); 2) a wider process that is rounded at the tip (Fig. 4b); and 3) a broad, truncate process (Fig. 4c). In fact, this character is dependent on the width of the space between the metacoxae and correlated with the width of the stalk of the metendosternite. Another correlation is with the degree of development of the metathoracic wings, as groups with very widely separated metacoxae tend (exceptions occur) to be brachypterous or apterous. An acute angle is formed when the mesal edges of the metacoxa touch or nearly touch along the posterior margin of the metaventrite, pinching ventrite I into an acute angle in the process. The rounded state is when the metacoxae are clearly but narrowly separated, and the broad condition is when the metacoxae are fairly distant from each other. Given the fact that this character is a stand-in for a whole suite of morphological changes, it is a more important character than might be seen at first glance, but it is also subject to extensive convergence.

Ventrite Sutures Connate. Ventrites I-V are abdominal sternites 3-7 in the Colydiinae. They may all bend freely (Fig. 4a, c), or two or three of them may be fused together in a more-or-less immovable platform (Fig. 4b). This fused group is referred to as connate. The easiest way to determine if ventrites are connate is to compare the division of the VI-V joint with the earlier ones. The last ventrite must hinge in order for the apex of the abdomen to open for defecation and mating. Thus, its division is the point of reference for those between the anterior ventrites. If there is a significantly different division between earlier ventrites than between $\mathrm{VI}-\mathrm{V}$, they are probably connate. The upturned lateral portions of the ventrites normally held against the inside of the elytral epipleuron are also an excellent place to determine connation. The gold standard method, however, is to remove the abdomen, relax and clear it, and see if the ventrites are mobile relative to each other.

Ventrite Sutures. When looking at the abdomen from below, if the sutures between ventrites 


\section{3}
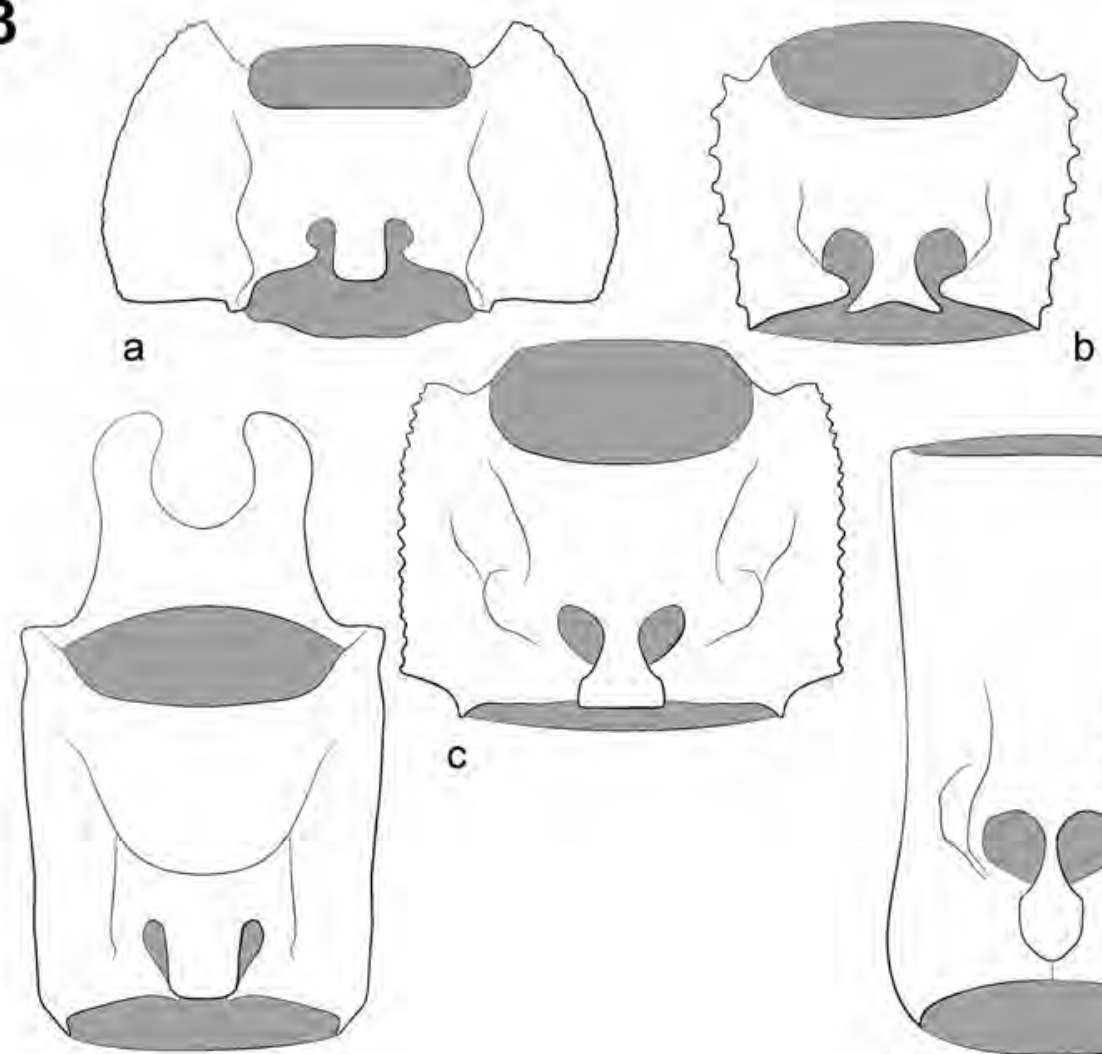

b

d

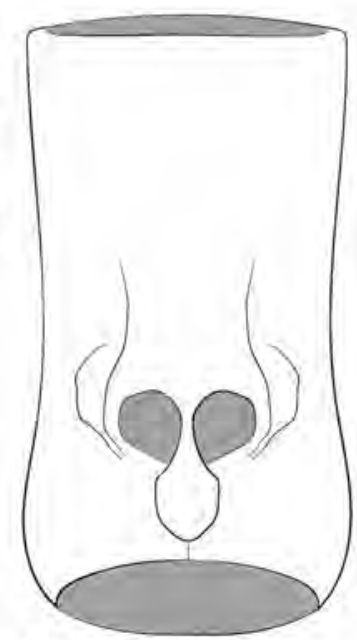

e

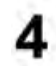

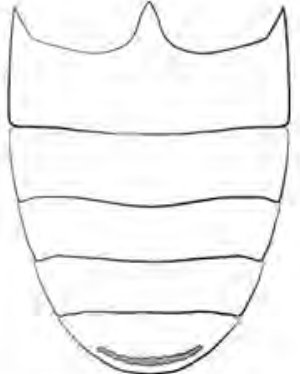

a

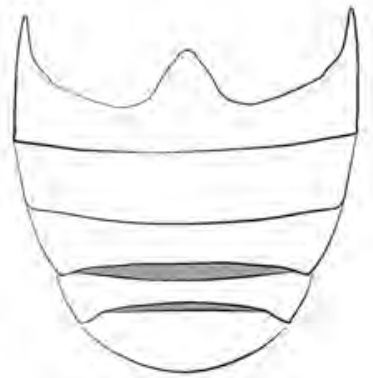

b

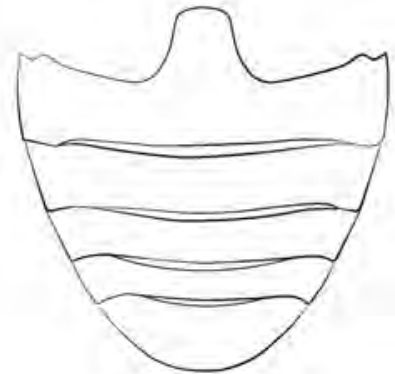

C

Figs. 3-4. Colydiinae anatomy. 3) Prothoraces, ventral view, illustrating procoxal cavity closure (external). a) Broadly open (Holopleuridia sp.), b) Narrowly open (Monoedus sp.), c) Moderately closed (Lasconotus sp.), d) Narrowly closed (Lobogestoria sp.), e) Broadly closed (Nematidium sp.); 4) Abdomina, ventral view. a) Intercoxal process acute, ventrites free, sutures flat, ventrite $\mathrm{V}$ with subapical groove, b) Intercoxal process broadly rounded, ventrites I-III connate, c) Intercoxal process truncate, ventrites free, sutures deeply impressed. 


\section{5}

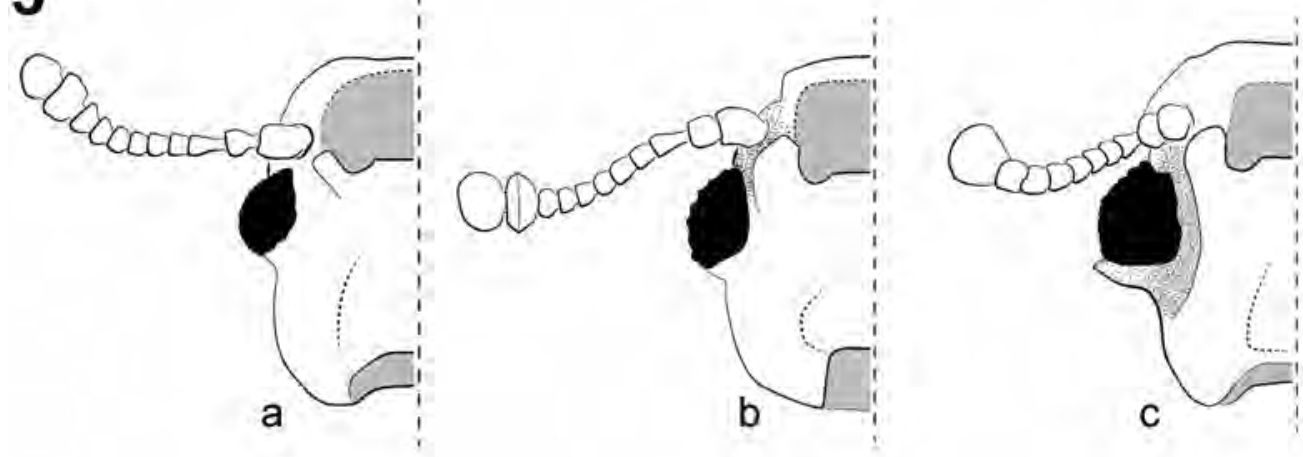

6

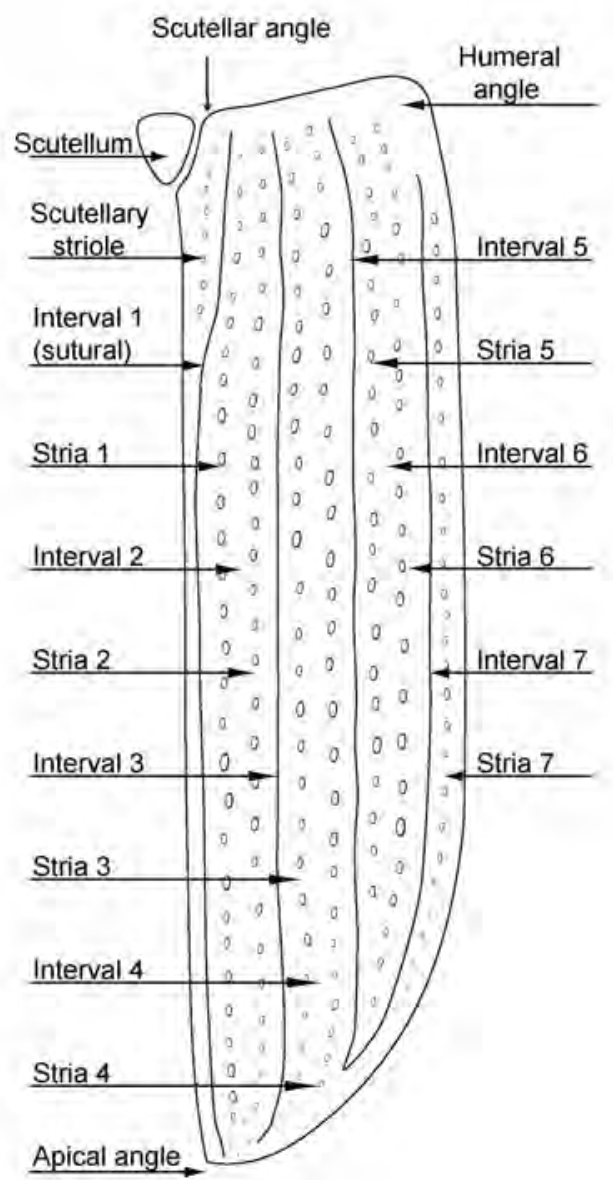

Figs. 5-6. Colydiinae anatomy. 5) Heads, ventral view, illustrating the antennal groove. a) Antennal groove absent, b) Antennal groove short, not reaching midpoint of eye, c) Antennal groove long, reaching past midpoint of eye; 6) Generalized elytron, illustrating the alternating intervals and interstriae. 
are virtually smooth and not grooved, they are termed flat (Fig. 4a). If there is a deep groove between them, they are termed deeply impressed (Fig. 4c). The flat condition is independent of connation and may be fully flexible. One way of thinking about this is that if a tiny hair or bristle were laid on the suture and the abdomen flexed back and forth, it would not be pinched by the flat condition, but would be caught between ventrites in the deeply impressed condition.

Grooved Ventrite V. In many zopherines, and a few colydiines, there is a groove on the last ventrite that more-or-less parallels the hind margin (Fig. 4a). This groove is fully ventral and visible only from below. It is not coincident with the hind or anterior margin, but is completely separate. When present, it is obvious. When absent, excessive examination can lead to misinterpretation.

\section{KeYS}

\section{Key to the Tribes and Non-Synchitine Genera of New World Colydinae}

(Key limited to New World members for groups with Old World representatives; for world key to tribes, see Ślipiński and Burakowski 1988.)

1. Unique habitus (Fig. 53); pronotum with incomplete, parallel, narrowly impressed grooves, deep pit laterally, just above complete, finely carinate lateral margin; lateral areas of pronotum otherwise unmodified; male metatibia with expanded, emarginate, hooked, or otherwise modified inner edge; $7^{\text {th }}$ and $8^{\text {th }}$ tergites fused into sclerotized pygidium; (remaining characters best seen in cleared specimens) ventrite I with postcoxal lines; abdomen with 2 connate ventrites; female with sclerotized spermatheca and very long spiculum ventrale; wing lacking medial fleck; less than $4 \mathrm{~mm}$ in length ................Phreatus (incertae sedis)

$1^{\prime}$. Not matching the above suite of characters

2(1'). Head heart-shaped, head capsule excavate behind posterior margin of eyes, eyes thereby projecting postero-laterally to form unique "bug-eyed" look (Figs. 7-9); head narrowed, subtriangular from tips of eyes to front, epistoma bulging, mouth cavity appearing narrow in comparison and displaced posteriorly; antenna short; Neotropical (Acropini).

2'. Head not as above; antenna variable; widespread.
3(2). Supraorbital crest short, present only around eye; dorsal surface of elytra smooth, lacking elevated nodules or ridge (Fig. 8); ventral surface of tarsomeres with dark, thick, spine-like setae; Central and South America

Ethelema

$3^{\prime}$. Supraorbital crest long, extending to margin of epistoma; dorsal surface of elytra usually with distinct elevated nodules, rarely smooth; ventral surface of tarsomeres with hair-like golden setae.....

$4\left(3^{\prime}\right)$. Dorsal pronotal setae obviously inserted in large, coarse tubercles; eye variable, very strongly to moderately expanded, extremely elongate to circular (Fig. 7); elytra lacking scutellary striole; Central and South America Acropis

4'. Dorsal pronotal setae inserted in very small (not clearly visible at $40 \mathrm{X}$ ) tubercles, punctures, and/or on smooth cuticle; eye weakly expanded (Fig. 9), always circular to subcircular in lateral view; elytra with scutellary striole; West Indies ...... Plagiope

$5\left(2^{\prime}\right)$. Body long, thin, cylindrical, prothorax long, impressed laterally for reception of legs (as in Fig. 3e); outer angle of tibial apex in the form of a projecting tooth ..............6 6

$5^{\prime}$. Body variable, seldom truly cylindrical, if so, lacking lateral impressions for reception of legs; outer angle of tibial apex not toothed.

6(5). Margin of frons arcuate, exposing lateral corner of mandibular base in frontal view; lateral margin of pronotum incomplete posteriorly (Fig. 15); $1^{\text {st }}$ tarsomere long and thin, as long as $2^{\text {nd }}+3^{\text {rd }}$ (Fig. 2a); antennal club distinctly 2-segmented (as in Fig. 1d-e) (Nematidiini).........Nematidium

6'. Margin of frons broadly rounded, covering mandibular base; lateral margin of pronotum complete (Fig. 14); $1^{\text {st }}$ tarsomere stout, not as long as $2^{\text {nd }}+3^{\text {rd }}$; antenna gradually clavate from antennomere 4 or 5 (Fig. 1i), with sensory patches starting on antennomere 4 or 5 (Gempylodini) ......... Endestes

$7\left(5^{\prime}\right)$. Pronotum bare, obvious setae absent at $40 \mathrm{X}$; $1^{\text {st }}$ tarsomere usually as long as $2^{\text {nd }}+3^{\text {rd }}$ (longer than $2^{\text {nd }}$, but shorter than $2^{\text {nd }}+3^{\text {rd }}$ in some Pseudaulonium) (Colydiini) ............. 8

7'. Pronotum variously setose, with sparse to dense, obvious setae of a variety of types, from hair-like to club-shaped to scale-like; $1^{\text {st }}$ tarsomere never as long as $2^{\text {nd }}+3^{\text {rd }} \ldots .11$

8(7). Elytra with alternate intervals strongly carinate, at least on declivity .................9

$8^{\prime}$. Elytra simple, with at most the $6^{\text {th }}$ stria grooved basally. 10 
9(8). Pronotum lacking distinct, strong carinae except occasionally laterad elytral interval 3 (Fig. 12); last visible sternite with pair of long setae on hind margin ....

\section{Colydium}

9'. Pronotum with 2 pairs of strong, acute, longitudinal carinae on disc, inner pair at or between elytral interval 3 (Fig. 10); last visible sternite without paired setae

Anarmostes

10(8'). Pronotum with strong sublateral carinae (Fig. 11), disc variously ornamented by tubercles, striae, or carinae; elytron with or without $6^{\text {th }}$ stria grooved basally.........

Aulonium

10'. Pronotum with weak sublateral carinae, disc plain (Fig. 13); elytron plain ....

Pseudaulonium

11(7'). Tegmen ventral; antenna with 3 -segmented club, appearing indistinct because of basket-like ring of curved, wide setae on antennomeres 4-8 making flagellomeres appear as broad as club segments (Fig. 1h); mouth distinctly prognathous; gular horns strong, bi- or tri-spinose anteriorly (covered with strong setae which may obscure character); body broad, elongate, distinctly flattened; elytra with suture raised, intervals 3, 5, and 7 acutely costate and straight on basal 3/4 (Fig. 16); head distinctly wider in front of eyes; moderately large species (4-10 mm), restricted to North American deserts of Mexico and USA (Rhagoderini) Rhagodera

11'. Tegmen dorsal; antenna distinctly 1-, 2-, or 3-segmented; mouth often directed somewhat downward; gular horns, if strong, not spinose anteriorly; size, body form, elytra, and head shape widely variable, but characters not in above combination; widespread (Synchitini) (go to Synchitini key)

\section{Key to the Genera of New World Synchitini}

1. Tarsi 3-3-3 or apparently 3-3-3; if actually $4-4-4,1^{\text {st }}$ true (of 4) tarsomere either strongly lobed, concealing $2^{\text {nd }}$ tarsomere (as in Fig. 2e) or very short, not extending beyond tibial insertion cavity (occasionally setation of hidden $1^{\text {st }}$ tarsomere visible in lateral or ventral aspect, but body of segment is greatly reduced; Fig. 2b)....... 2

$1^{\prime}$. Tarsi clearly $4-4-4,1^{\text {st }}$ tarsomere clearly visible............................................. 10

2(1). Eyeless (Fig. 49); tarsi truly $3-3-3 ;<1.5 \mathrm{~mm}$ in length; soil dwelling; Chile .......... Reylus $2^{\prime}$. Eyes present, sometimes reduced; tarsi actually 4-4-4; > $2 \mathrm{~mm}$ in length; widespread....

$3\left(2^{\prime}\right)$. First tarsomere lobed, long below, hiding true $2^{\text {nd }}$ tarsomere (as in Fig. 2e); antennal club 1-segmented (similar to Fig. 1a); eyes small to very small ................................... 4

$3^{\prime}$. First tarsomere very short, hidden in tibial excavation (as in Fig. 2b); antennal club usually 2-segmented (1-segmented in Hawaii species); eyes normal

4(3). Pronotum subquadrate, lateral margins nearly straight, sometimes widened slightly anteriorly; $1^{\text {st }}$ tarsomere very large, ventral lobe reaching last tarsomere with an obvious fleshy setose pad (as in Fig. 2e) ................ 5

4'. Pronotum rounded laterally, widest near middle (Fig. 48); $1^{\text {st }}$ tarsomere not large, ventral lobe not reaching last tarsomere, without fleshy setose lobe........... Rapthius

5(4). First tarsomere broad and heart- or paddleshaped, much wider than other segments (Fig. 2e); protibia variously widened in midsection (Fig. 36). Monoedus

5'. First tarsomere narrow, little wider than others, pointed or narrowly rounded apically; protibia narrow throughout (Fig. 51)

Stenomonoedus

6(3'). Body short and broad (Fig. 28); pronotum lacking obvious mid-lateral secretory pores .. Globotrichus

6'. Body elongate, cylindrical or elongateflattened; pronotum with obvious midlateral secretory pores (specimen must be clean).

$7\left(6^{\prime}\right)$. Pronotum with deep, wide, smoothbottomed lateral longitudinal canals associated with mid-lateral secretory pore; pronotum with or without horns or swellings anteriorly

7'. Medio-lateral secretory pore without associated linear canal, laterally with enlarged microtubercles; pronotum without swellings or horns anteriorly (Fig. 38)......Neotrichus

8(7). Antenna with 1-segmented club (as in Fig. 1a-c); anterior margin of pronotum lacking swellings or horns (Fig. 18); Hawaii

..Antilissus

8'. Antenna with 2-segmented club (as in Fig. 1d-e); anterior margin of pronotum with large swellings or projecting horns ....9

$9\left(8^{\prime}\right)$. Anterior margin of pronotum with nodular swellings, separated posteriorly from disc by deep transverse canal (Fig. 22); elytra bearing scale-like setae; apical margin simple

..Colydodes

9'. Pronotum with pair of anterior pronotal horns extending above head (Fig. 3d); elytra 
glabrous, with upturned apical margin (Fig. 32) Lobogestoria

10(1'). Labial palpi absent (caution: expanded galea may appear like labial palps); habitus as in Fig. 46; southern South America

Pristoderus

10'. Labial palpi present; widespread ........11

$11\left(10^{\prime}\right)$. Procoxal cavities closed externally (as in Fig. 3c-e); antennal club 2-segmented (as in Fig. 1d-e) or 3-segmented (as in Fig. 1f-h); if procoxal cavities narrowly open, antennal club 3-segmented (check carefully - procoxal closure difficult to see in some Chilean specimens, where the closure is below the level of the prosternal process and very narrow)......... 12

11'. Procoxal cavities open externally, sometimes narrowly so (as in Fig. 3a-b); antennal club 1-segmented (as in Fig. 1a-c) or 2-segmented (as in Fig. 1d-e) ........... 14

12(11). Procoxal cavities narrowly open (rare) or closed by mesad extension of hypomeron (common; Fig. 3c), prosternal process not expanded apically beyond midpoint of procoxa; antennal club 3-segmented (Figs. 1f, 31), very rarely 2 -segmented; supraocular carina variable; if antennal club 2-segmented, supraocular carina strong................. Lasconotus

12'. Procoxal cavities closed by laterad extension of prosternal process; antennal club 2-segmented (as in Fig. 1d-e); supraocular carina weak to absent.....13

$13\left(12^{\prime}\right)$. Procoxal closures on the same plane with ventral surface of intercoxal process; fully winged; last ventrite lacking marginal groove; posterior margin of eye lacking canthus (Fig. 37); Northern Hemisphere.

Namunaria

13'. Procoxal closures located dorsad of ventral plane of intercoxal process (i.e., recessed and difficult to see); lacking metathoracic wings; last ventrite with marginal groove (as in Fig. 4a); posterior margin of eye with small triangular canthus (Fig. 39); Southern Hemisphere

Notocoxelus

14(11'). Antennal club with 2 expanded sensory segments (10-11), segment 9 triangular or transverse, 10 and 11 articulated and not forming a continuous mass (as in Fig. 1d-e) .

14'. Antennal club with expanded sensory segments appearing 1-segmented, fused, or not articulated and forming a continuous mass (as in Fig. 1a-c)

15(14). Hypomeron with deep, margined pocket that engulfs antennal club.
15'. Hypomeron with at most shallow depressions on anterior portion ..........17

16(15). Notosternal sutures depressed to receive tarsi; sutures between ventrites I-III deeply impressed (similar to Fig. 4c); habitus as in Fig. 34 .........Megataphrus

16'. Notosternal sutures flat; sutures between ventrites I-III flat, not impressed (similar to Fig. 4a); habitus as in Fig. 50 Slipinskius

17(15'). Body $4 \mathrm{X}$ as long as wide (Fig. 27)

Eudesma

17'. Body less than $4 \mathrm{X}$ as long as wide, at most $3 \mathrm{X}$ as long as wide .................... 18

$18\left(17^{\prime}\right)$. Intercoxal process of ventrite I truncate or rounded (as in Fig. 4b-c).............. 19

18'. Intercoxal process of ventrite I acute (as in Fig. 4a) ....................................22

19(18). Eyeless (Fig. 33); Alabama, USA.... Lyreus 19'. Eyes present, often small; widespread (if Chilean, see couplets 11 and 12)....20

20(19'). Pronotum subparallel or widest behind middle (as in Fig. 3a); metaventrite regular to elongate, more than half as long as metafemur (measured between midline of meso- and metacoxa); winged; eyes large, round or longitudinal (Fig. 30)

Holopleuridia

20'. Pronotum widest in front of middle, narrowed at anterior angles; metaventrite short, less than half as long as metafemur (measured between midline of meso- and metacoxa); wingless; eyes small, round or vertical .......................21

21(20'). Antennal groove short (as in Fig. 5b); scales narrow or hair-like; pronotum evenly rounded laterally (Fig. 23)

\section{Coxelus}

21'. Antennal groove long (as in Fig. 5c); scales wide; pronotum strongly lyriform (Fig. 43).

Pharax

22(18'). Pronotum with tuberculate ridges; elytra with complex carinae or tubercles.....23

22'. Pronotum and elytra with weak to strong, simple carinae .24

23(22). Antenna slender, shiny, sparsely clothed in suberect, fine setae; eye with weak supra-antennal ridge extending to anterior margin of eye; smaller $<5 \mathrm{~mm}$ (Fig. 29); Central America ......Helonoton

23'. Antenna stout, thick, rugose, dull, moderately clothed with recumbent stout setae; eye with strong supra-antennal ridge extending past anterior margin of eye; length $>6 \mathrm{~mm}$ (Fig. 24); North America ........................... Denophoelus

$24\left(22^{\prime}\right)$. Lateral margins of frons continuous with supraocular carinae .25 
24'. Lateral margins of frons ending at mideye level as a canthus or notch, not continuous with supraocular carina....28

25(24). Antennal groove long, reaching to or beyond posterior edge of eye (as in Fig. 5c) ..........................................26

25'. Antennal groove short, not reaching beyond midpoint of eye (as in Fig. 5b); habitus as in Fig. 20

Bitoma

26(25). Antennal segment 3 very long, equal to or longer than 4-6 combined (as in Fig. 1d); pronotal disc without carinae (Fig. 21) Colobicus

26'. Antennal segment 3 short, equal to or shorter than 4-5 combined (as in Fig. 1e); pronotal disc with carinae ..................... 27

$27\left(26^{\prime}\right)$. Elytron oblique laterally, lateral margin clearly visible in dorsal view (Fig. 17), interval 9 weakly to obscurely carinate Acolobicus

27'. Elytron vertical laterally, lateral margin obscured in dorsal view, interval 9 strongly carinate (Fig. 35)....Microprius

$28\left(24^{\prime}\right)$. Median pair of pronotal carinae diverging medially, encircling mid-discal area, and forked behind this encirclement (Fig. 45); antennal groove moderately long, hypomeron without depressions for antennae; parameres asetose

.Phloeonemus

28'. Median pair of pronotal carinae more or less parallel (Fig. 44); antennal groove long, curved behind the eye, and continuous with antennal depressions in antero-lateral corners of pronotum; parameres setose......... Phloeodalis (in part)

$29\left(14^{\prime}\right)$. Elytra with scutellary striole (Fig. 6) .... 30

29'. Elytra lacking scutellary striole (Fig. 6)

30(29). Lateral margin of frons extending into eye as a short canthus (Fig. 44); tempora absent; last antennomere rounded (see couplet 28). Phloeodalis (in part)

30'. Lateral margin of frons not entering eye (Fig. 42); tempora forming acute tooth behind eye (Fig. 5c); antennal club abruptly truncate apically Paxillobitoma

31(29'). Dorsum lacking obvious setae (Fig. 40); when present and viewed under high magnification (40X), setae hair-like and shorter than width of punctures or tubercles from which they arise. Paha

31'. Dorsum with obvious setae; setae either distinctly scale-like or clearly longer than width of punctures or tubercles from which they arise ..32

$32\left(31^{\prime}\right)$. Setae hair-like; pronotum subparallel or widest at middle. .33
32'. Setae usually scale-like or bristle-like, rarely hair-like; pronotum variable; if setae hair-like, pronotum distinctly widest anteriorly ................................34

33(32). Pronotum transverse to subquadrate (Fig. 25); antennomere $33 \mathrm{X}$ as long as wide, as long as 1-2 or 4-6 combined (Fig. 1a)

Endeitoma

33'. Pronotum elongate (Fig. 19); antennomere 3 only as long as $4-5$, less than $2 \mathrm{X}$ as long as wide, subequal to 1

Asynchita

$34\left(32^{\prime}\right)$. Pronotum distinctly wider across anterior angles than across posterior angles..... 35

34'. Pronotum as wide or wider at posterior angles than at anterior angles ............36

35(34). Antennae with sparse, hair-like setae; eyes sparsely scaled; antennae short (Fig. 41), antennomere 2 longer and wider than 3 .....

Paryphus

35'. Antennae with scale-like setae; eyes densely scaled; antennae longer, reaching approximately to midpoint of pronotum (Fig. 47), antennomere 3 longer than and as wide as 2 ..................Pseudocorticus

$36\left(34^{\prime}\right)$. Antennal groove long, curved, and reaching to at least middle of eye (as in Fig. 5c); habitus as in Fig. 26.

Eucicones

36'. Antennal groove short and straight to obsolete, with groove restricted to smooth portion at point of antennal insertion (rugose thereafter, at most weakly depressed; similar to Fig. 5a-b); habitus as in Fig. 52 . Synchita

\section{Checklists of the Genera and Species of New World Colydinae}

Full nomenclatural citations are given, and included in References Cited below, for all species considered valid today. Full citations are also given for new taxonomic acts presented herein or those not covered in the following papers: Hetschko (1930); Blackwelder (1945); Stephan (1989); Ivie and Ślipiński (1990); Ślipiński and Lawrence (1997); Węgrzynowicz (1999); Ivie (2002); Lord and Leschen (2014). Year and pagination for each name that is unchanged since the works above are included as a convenience and the citations included in the References Cited below. An asterisk (*) denotes the type species of the genus. If no species bears an asterisk, then the type species is Old World. A name in square brackets after the species epithet indicates the 
original generic name. Sums of species numbers include only New World species.

\section{TRIBE ACROPINI Sharp, 1894}

(3 genera, 21 species)

Acropis Burmeister, 1840

(Fig. 7)

Acropis Burmeister 1840: 73. (12 species)

Lemmis Pascoe 1860: 106. New synonymy.

Currently recognized species of Acropis:

aspera Pascoe 1860: 106.

incensa Pascoe 1860: 106. New synonymy.

caelata Pascoe 1860: 107. New combination [from Lemmis].

championi Sharp 1894b: 476

denticulata Hinton 1936: 77.

discoidea Reitter 1877a: 333.

maracapatana Heinze 1954: 167.

recta Sharp 1894b: 476.

serrata Sharp 1894b: 476.

steinheili Reitter 1877a: 332.

tristis Reitter 1877a: 333.

*tuberculifera Burmeister 1840: 74.

fryi Pascoe 1860: 105. New synonymy.

tuberosa (Grouvelle 1896b: 187). New combination [from Lemnis (sic)].

\section{Ethelema Pascoe, 1860}

(Fig. 8)

Ethelema Pascoe 1860: 107. (5 species)

Currently recognized species of Ethelema: costaricensis Nevermann 1930: 110.

decorata Sharp 1894b: 477.

*luctuosa Pascoe 1860: 107.

nigrogrisea (Grouvelle 1914: 49). New combination [from Lemmis].

sobrina Sharp 1894b: 477.

\section{Plagiope Erichson, 1845}

(Fig. 9)

Plagiope Erichson 1845: 258. (4 species)

Currently recognized species of Plagiope:

cubana (Zayas 1988: 78). New combination [from Ethelema].

denticulata (Grouvelle 1898a: 39). New combination [from Lemnis (sic)].

Iherminieri (Grouvelle 1902: 760). New combination [from Lemnis (sic)].

*tuberculata Erichson 1845: 258.
TRIBE COLYDIINI Erichson, 1842

(4 genera, 80 species)

Anarmostes Pascoe, 1860

(Fig. 10)

Anarmostes Pascoe 1860: 110. (11 species) Eulachus Erichson 1845: 275. New synonymy.

Currently recognized species of Anarmostes:

argutus Sharp 1894b: 471.

ater Dajoz 1984b: 163.

bicolor Pascoe 1863b: 89.

carinatus (Kirsch 1865: 46) [Colydium].

costatus (Erichson 1845: 275). New combina-

tion [from Eulachus].

costicollis Reitter 1877a: 342.

elongatus Dajoz 1984b: 163.

granulosus Dajoz 1984b: 163.

laticollis Pascoe 1863b: 89.

*sculptilis Pascoe 1860: 110.

vicinus Dajoz 1984b: 162.

\section{Aulonium Erichson, 1845}

(Fig. 11)

Aulonium Erichson, 1845: 275. (25 species)

Currently recognized New World species of Aulonium:

aequicolle LeConte 1859a: 81.

angustatum Pascoe 1863b: 86.

belti Sharp 1894b: 469.

*bidentatum (Fabricius 1801: 556) [Colydium]. cylindricum Hinton 1936: 55.

egens Pascoe 1863b: 88.

ferrugineum Zimmermann 1869: 254.

frontale Sharp 1894b: 469.

grandis Dajoz 1980b: 339.

guyanense Dajoz 1980b: 333.

hebes Pascoe 1863b: 88.

ignotum Pascoe 1863b: 87.

insigne Reitter 1877a: 336.

longicolle Dajoz 1980b: 338.

longum LeConte 1866: 378.

minutum Dajoz 1980b: 330.

oblitum Pascoe 1863b: 87.

parallelopipedum (Say 1826: 263) [Colydium]. chilense Dajoz 1980b: 335. [Synonymy by Ivie et al. (2001)].

praepositum Pascoe 1863b: 88.

sublaeve Pascoe 1863b: 87.

thoracicum Dajoz 1980b: 336.

tuberculatum LeConte 1863: 67.

tubulum Sharp 1894b: 469.

ulomoides (Pascoe 1860: 100) [Gloeania].

vicinum Dajoz 1980b: 332. 

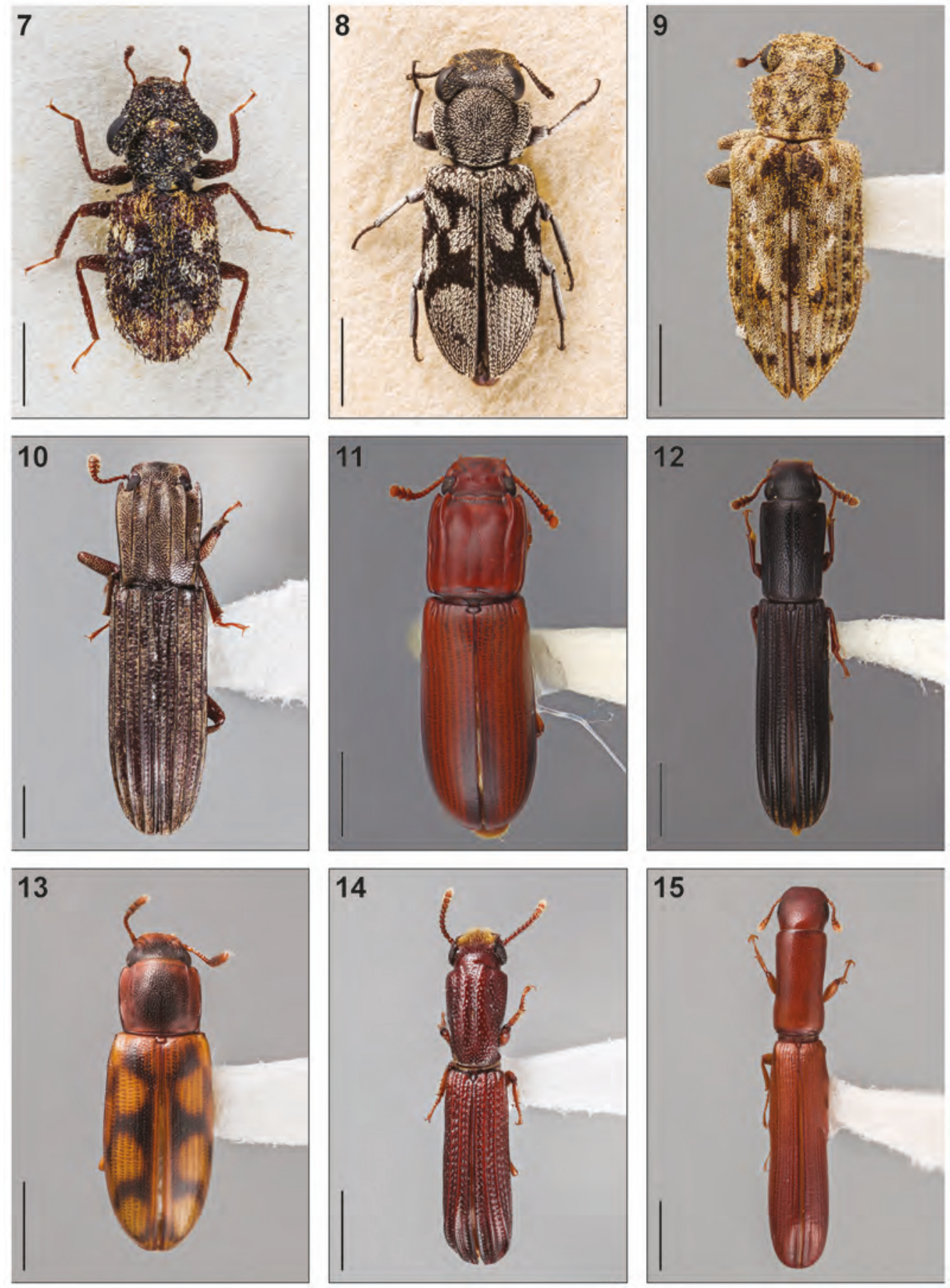

Figs. 7-15. Dorsal habitus of New World colydiine genera, tribes Acropini, Colydiini, Gempylodini, and Nematidiini. 7) Acropis maracapatana; 8) Ethelema costaricensis; 9) Plagiope tuberculata; 10) Anarmostes ater; 11) Aulonium longum; 12) Colydium lineola; 13) Pseudaulonium sp., Venezuela; 14) Endestes incilis; 15) Nematidium filiforme. 
Colydium Fabricius, 1792

(Fig. 12)

Colydium Fabricius 1792: 495. (30 species)

Currently recognized New World species of Colydium:

acuticolle Reitter 1878b: 119.

bicarinipenne Hinton 1936: 51.

brevicorne Reitter 187b: 119.

burakowskii Węgrzynowicz 1999: 278.

championi Sharp 1894b: 467.

chiriquense Sharp 1894b: 466.

clavigerum Sharp 1894b: 468.

clypeale Hinton 1936: 52.

corpulentum Reitter 1878b: 117

ferrugineum Reitter 1878b: 120.

glabriculum Stephan 1989: 55.

godmani Sharp 1894b: 465.

guatemalenum Sharp 1894b: 466.

holynskiorum Węgrzynowicz 1999: 295.

latum Hinton 1936: 49.

lineola Say 1826: 264.

longicolle Reitter 1878b: 118.

manfredi Węgrzynowicz 1999: 303.

marleyi Węgrzynowicz 1999: 306.

mexicanum Reitter 1878b: 118.

nigripenne LeConte 1863: 67.

pascoei Reitter 1877b: 23.

plaumanni Węgrzynowicz 1999: 310.

puncticolle Sharp 1894b: 467.

pusillum Sharp 1894b: 468.

robustum Stephan 1989: 55.

ruficorne Fabricius 1801: 557.

slipinskii Węgrzynowicz 1999: 324.

thomasi Stephan 1989: 57.

unistriatum Reitter 1878b: 116.

\section{Pseudaulonium Reitter, 1877}

(Fig. 13)

Pseudaulonium Reitter 1877a: 334. (14 species)

Currently recognized species of Pseudaulonium:

boliviense Dajoz 1984b: 158.

carinatum Dajoz 1984b: 154.

convexum Dajoz 1984b: 157.

crassum Dajoz 1984b: 155.

denticulatum Dajoz 1984b: 154.

depressum Dajoz 1984b: 156.

discolor Champion 1913: 74.

ferrugineum Reitter 1877a: 336.

gounellei Dajoz 1984b: 155.

latum Dajoz 1984b: 156.

mexicanum Dajoz 1984b: 154.

nitidum Champion 1913: 75.

*regale Reitter 1877a: 335.

titschacki Heinze 1954: 159.
TRIBE GEMPYLODINI Sharp, 1893

(1 genus, 2 species)

Endestes Pascoe, 1863

(Fig. 14)

Endestes Pascoe 1863b: 91. (2 species)

Currently recognized New World species of Endestes:

*incilis Pascoe 1863b: 92.

sculpturatus Sharp 1894b: 472. New synonymy. sulcicollis Reitter 1877a: 337.

\section{TRIBE NEMATIDIINI Sharp, 1894}

(1 genus, 11 species)

Nematidium Erichson, 1845

(Fig. 15)

Nematidium Erichson 1845: 275. (11 species)

Currently recognized New World species of Nematidium:

argentinum Dajoz 1984a: 150.

confusum Dajoz 1984a: 149.

constrictum Dajoz 1984a: 149.

*cylindricum (Fabricius 1801: 557).

filarium Sharp 1894b: 479.

filiforme LeConte 1863: 68.

fryanum Sharp 1894b: 478.

pascoei Arrow 1909: 193.

peruvianum Heinze 1954: 165.

strictum Dajoz 1984a: 148.

viverra Sharp 1894b: 479.

\section{TRIBE RHAGODERINI \\ LeConte and Horn, 1883 \\ (1 genus, 6 species)}

Rhagodera Mannerheim, 1843

(Fig. 16)

Rhagodera Mannerheim 1843: 269. (6 species)

Currently recognized species of Rhagodera:

costaefragmenta Krinsky 2015: 293.

costata Horn 1867: 295.

interrupta Stephan 1989: 22.

laticeps Blaisdell 1925: 326.

texana Stephan 1989: 23.

*tuberculata (Mannerheim 1843: 300).

TRIBE SYNCHITINI Erichson, 1845

(36 genera, 183 species)

Adimerini Sharp 1894b: 441. New synonymy. 

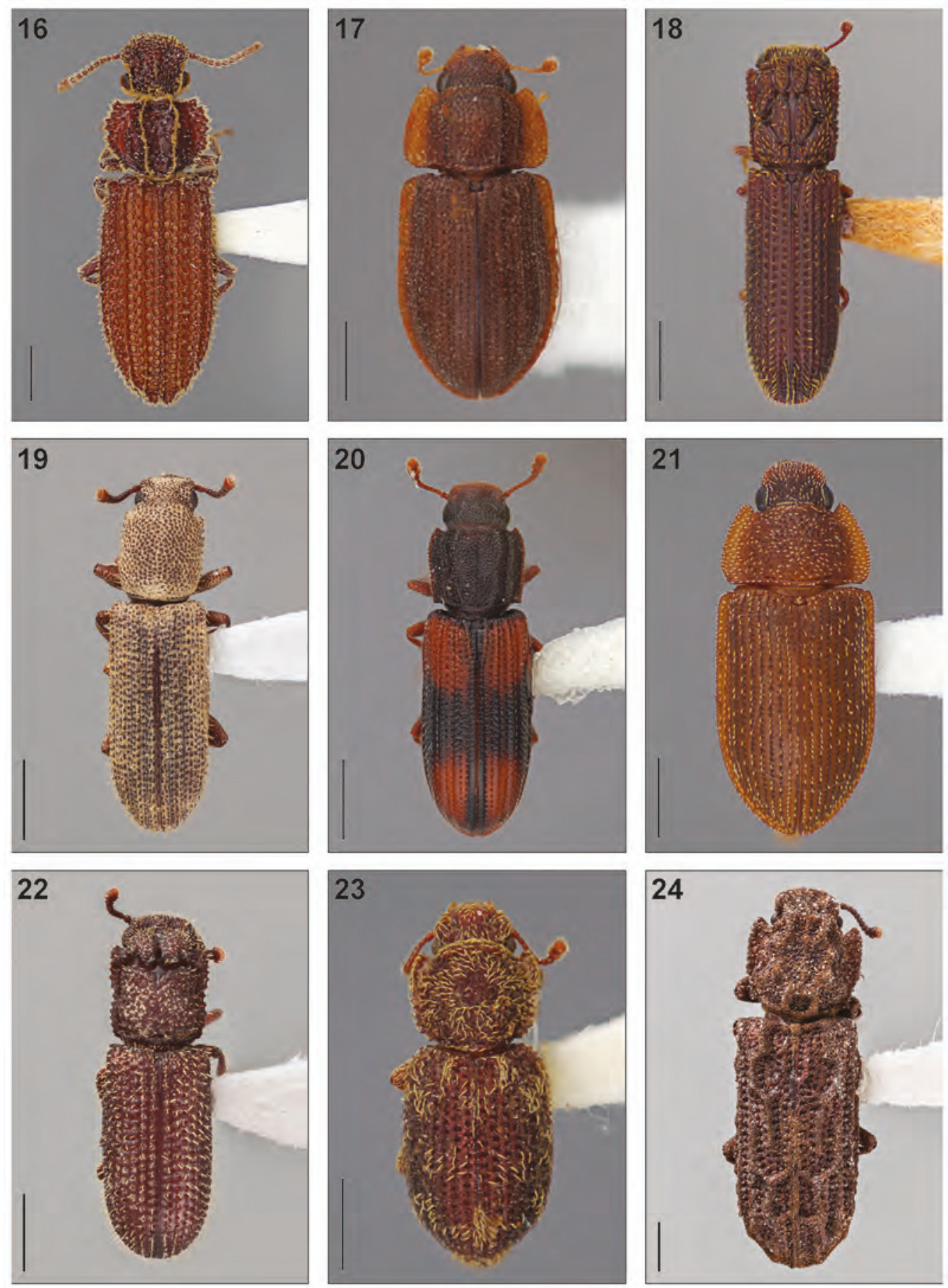

Figs. 16-24. Dorsal habitus of New World colydiine genera, tribes Rhagoderini and Synchitini. 16) Rhagodera texana; 17) Acolobicus erichsoni; 18) Antilissus aper; 19) Asynchita granosa; 20) Bitoma crenata; 21) Colobicus parilis; 22) Colydodes gibbiceps; 23) Coxelus serratus; 24) Denophoelus nosodermoides. 


\section{Acolobicus Sharp, 1894}

(Fig. 17)

Acolobicus Sharp 1894b: 452. (2 species)

Currently recognized species of Acolobicus: championi (Sharp 1894b: 454) [Ditaphrus]. erichsoni (Reitter 1877c: 133) [Phloeodalis].

Type species is the junior synonym.

*Acolobicus obscurus Sharp 1894b: 452.

\section{Antilissus Sharp, 1879}

(Fig. 18)

Antilissus Sharp 1879: 86. (1 species)

Currently recognized New World species of Antilissus:

*aper Sharp 1879: 86.

\section{Asynchita Sharp, 1894}

(Fig. 19)

Asynchita Sharp 1894b: 448. (2 species)

Currently recognized species of Asynchita:

*granosa Sharp 1894b: 449.

panamensis (Sharp 1894b: 450). New combi-

nation [from Endeitoma, transferred to Synchita by Hetschko (1930)].

\section{Bitoma Herbst, 1793}

(Fig. 20)

Bitoma Herbst 1793: 25. (28 species)

Currently recognized New World species of Bitoma:

brevipes (Sharp 1894b: 462) [Xuthia]. carinata (LeConte 1863: 68) [Eulachus]. centralis Sharp 1894b: 459.

*crenata (Fabricius 1775: 69) [Tritoma].

discolor Schaeffer 1907: 138.

exarata (Pascoe 1863b: 91) [Coniophaea]. gounellei (Grouvelle 1896b: 185) [Ditoma]. gracilis Sharp 1894b: 460.

granulata (Blatchley 1910: 552) [Ditoma].

intermedia Hinton 1935b: 202.

jejuna Pascoe 1860: 102.

longior (Grouvelle and Raffray 1908: 49) [Ditoma].

neglecta Stephan 1989: 42.

obscura (Fabricius 1801: 562) [Lyctus, see Ivie (2010)].

ornata LeConte 1858: 63.

palmarum Bondar 1940a: 114, 1940b: 852.

parvula Hinton 1936: 63.

pinicola Schaeffer 1907: 138.

quadricollis Horn 1885: 140.

quadriguttata Say 1826: 266. quinquecarinata (Chevrolat 1864: 609). New combination [from Eulachus].

semifuliginosa (Chevrolat 1864: 608). New combination [from Eulachus].

siviana Heinze 1954: 161.

socialis Pascoe 1863b: 81.

subfasciata Sharp 1894b: 459.

sublata Hinton 1936: 64.

sulcata LeConte 1858: 63.

unicolor Guérin-Méneville 1829: 194. [Ususally treated as undata, a lapsus calami of Hetschko (1930: 20), followed by Blackwelder (1945: 471) and subsequent authors].

vittata Schaeffer 1907: 137.

\section{Colobicus Latreille, 1807}

(Fig. 21)

Colobicus Latreille 1807: 9. (1 species)

Currently recognized New World species of Colobicus:

parilis Pascoe 1860: 102.

\section{Colydodes Motschulsky, 1855}

(Fig. 22)

Colydodes Motschulsky 1855: 13. (8 species)

Currently recognized New World species of Colydodes:

batesii Pascoe 1863b: 83.

flavisetis Ferreira and Ide-dos Santos 2015: 438. *gibbiceps Motschulsky 1855: 13.

mammillaris (Pascoe 1860: 104) [Distaphyla]. peruviensis Ivie and Ślipiński 1989: 246.

simplex Ivie and Ślipiński 1989: 247.

sparsus Hinton 1935a: 231.

\section{Coxelus Dejean, 1821}

(Fig. 23)

Coxelus Dejean 1821: 67. (2 species) Stephaniolus Ivie et al. 2001: 64. New synonymy.

Currently recognized New World species of Coxelus:

longus (Stephan 1989: 26). New combination [Pseudotaphrus, moved to Stephaniolus by Ivie et al. (2001)].

serratus Horn 1885: 142.

\section{Denophoelus Stephan, 1989}

(Fig. 24)

Denophoelus Stephan 1989: 44. (1 species)

Currently recognized species of Denophoelus: *nosodermoides (Horn 1878: 567) [Endophloeus]. 


\section{Endeitoma Sharp, 1894b}

(Fig. 25)

Endeitoma Sharp 1894b: 450. (4 species)

Currently recognized New World species of Endeitoma:

dentata (Horn 1885: 139) [Synchita].

granulata (Say 1826: 266) [Synchita, transferred to Asynchita by Hinton (1936), transferred to Endeitoma by Stephan (1989)].

*mexicana Sharp 1894b: 450.

rugulosa (Guérin-Méneville 1844: 189). New combination [Synchita, transferred to Asynchita by Hinton (1936)].

\section{Eucicones Sharp, 1894}

(Fig. 26)

Eucicones Sharp 1894b: 452. (6 species) Catolaemus Sharp 1894b: 457. New synonymy. Cacotarphius Sharp 1894b: 473. New synonymy.

Currently recognized species of Eucicones: compressus (Sharp 1894b: 473). New combination [from Cacotarphius]. gounellei Grouvelle 1896b: 186. marginalis (Melsheimer 1846: 112) [Cicones]. minutus (Sharp 1894b: 457). New combination [from Catolaemus].

*perfectus Sharp 1894b: 453.

uniformis Hinton 1936: 66.

\section{Eudesma LeConte, 1863}

(Fig. 27)

Eudesma LeConte 1863: 66. (1 species)

Currently recognized species of Eudesma:

*undulata (Melsheimer 1846: 110) [Bitoma].

Globotrichus Lord and Ivie, 2016

(Fig. 28)

Globotrichus Lord and Ivie 2016: 717. (1 species)

Currently recognized species of Globotrichus:

*harti Lord and Ivie 2016: 719.

\section{Helonoton Lord and Ivie, 2016}

(Fig. 29)

Helonoton Lord and Ivie 2016: 720. (12 species)

Currently recognized species of Helonoton: amistad Lord and Ivie 2016: 728. ashei Lord and Ivie 2016: 729. bituberculatum Lord and Ivie 2016: 730. chiriqui Lord and Ivie 2016: 731. *costaricense Lord and Ivie 2016: 733.

foleyi Lord and Ivie 2016: 735.

mexicanum Lord and Ivie 2016: 736. pascoei (Sharp 1894b: 461) [Bitoma]. pustulosum Lord and Ivie 2016: 739. tatumbla Lord and Ivie 2016: 740. tico Lord and Ivie 2016: 741.

tripartum Lord and Ivie 2016: 742.

Holopleuridia Reitter, 1876 (Fig. 30)

Holopleuridia Reitter 1876: 56. (4 species) Zanclea Pascoe 1863b: 80 [not Zanclea Gegenbaur, 1856]. New synonymy. Aneumesa Sharp 1894b: 455. New synonymy.

Currently recognized New World species of Holopleuridia:

atomaria (Sharp 1894b: 455). New combination [from Aneumesa].

costata (Sharp 1894b: 456). New combination [from Aneumesa].

*maculosa Reitter 1876: 57.

testudinea (Pascoe 1863b: 81) New combination [from Zanclea].

\section{Lasconotus Erichson, 1845}

(Fig. 31)

Lasconotus Erichson 1845: 258. (37 species) Lado Wankowicz 1867: 249 [Synonymy by Hinton (1935b: 204)].

Anisopaulax Reitter 1877a: 324. New synonymy.

Currently recognized New World species of Lasconotus:

apicalis Casey 1890: 315.

arrowi Hinton 1935b: 205.

atomus Grouvelle and Raffray 1908: 49.

bitomoides Kraus 1912: 40.

boliviensis Hinton 1935b: 204.

apicalis Grouvelle 1898b: 377 (not Casey 1890).

borealis Horn 1878: 570.

brucki (Reitter 1877a: 324). New combination [from Anisopaulax].

chilensis (Grouvelle 1898b: 378) [Lado].

ciliatus (Sharp 1894b: 463) [Lado].

*complex LeConte 1859b: 282.

concavus Casey 1890: 315.

coronatus (Hinton 1935b): 208 [Chrysopogonius]. elegans (Sharp 1894b: 463) [Lado].

fiskei Kraus 1912: 39.

fitzgibbonae Kingsolver, Stephan, and Moser 2006: 54 [= Chrysopogonius n. sp. of Stephan (1989) and Ivie (2002)]. 

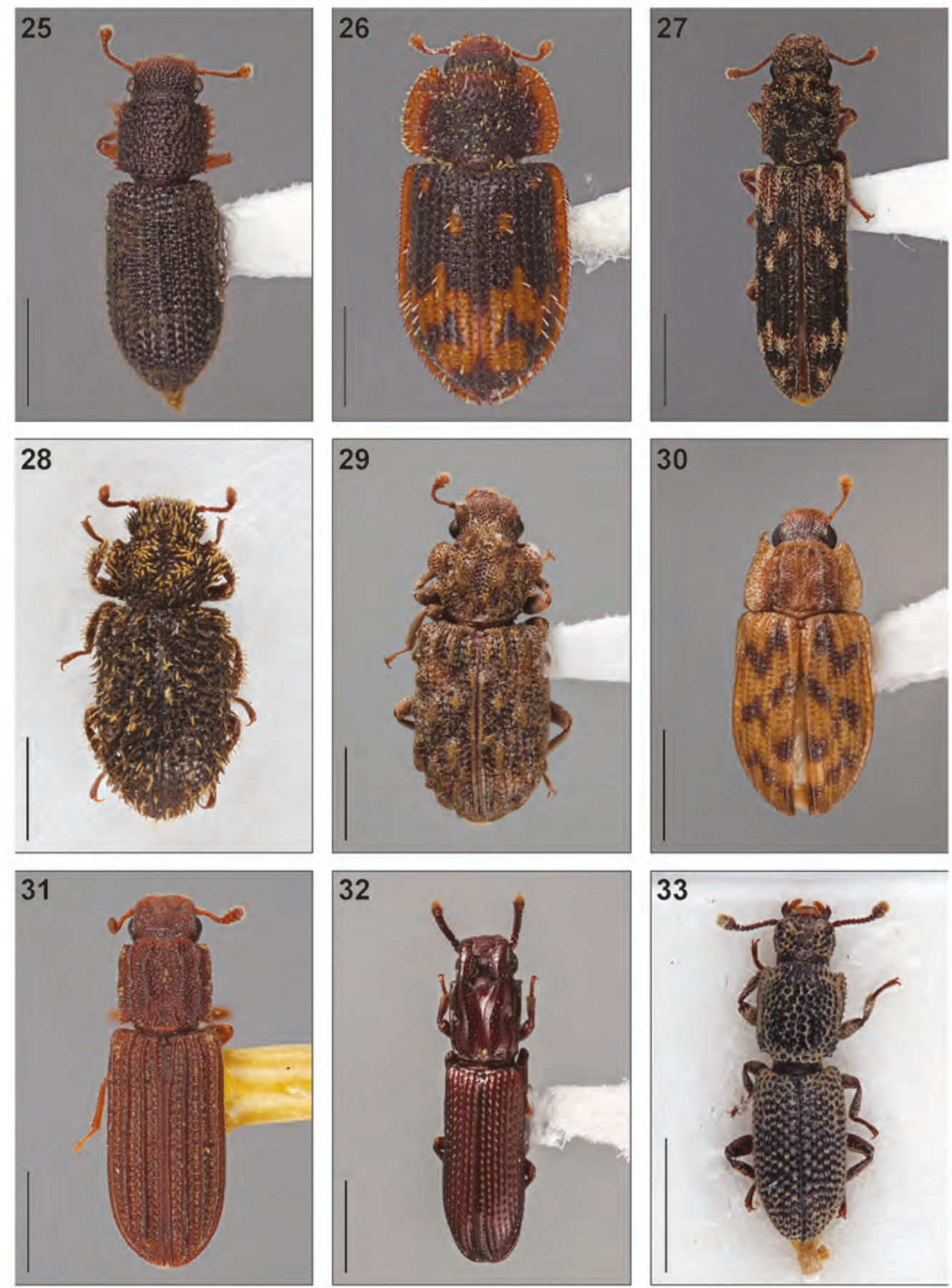

Figs. 25-33. Dorsal habitus of New World colydiine genera, tribe Synchitini. 25) Endeitoma dentata; 26) Eucicones marginalis; 27) Eudesma undulata; 28) Globotrichus harti; 29) Helonoton ashei; 30) Holopleuridia sp., Panama; 31) Lasconotus complex; 32) Lobogestoria gibbicollis; 33) Lyreus alleni. 
flexuosus Kraus 1912: 35.

funestus (Sharp 1894b: 464) [Lado]. germaini (Grouvelle 1898b: 376) [Lado]. intricatus Kraus 1912: 36.

knulli Stephan 1989: 48.

laqueatus LeConte 1866: 378.

linearis Crotch 1874: 75.

mexicanus Kraus 1912: 35.

nucleatus Casey 1890: 314.

perplexus (Grouvelle and Raffray 1913: 293) [Ithris].

pertenuis Casey 1890: 313.

planipennis Kraus 1912: 39.

pusillus LeConte 1863: 67.

referendarius Zimmermann 1869: 254.

servus Horn 1885: 141.

simplex LeConte 1866: 378.

subcostulatus Kraus 1912: 40.

sulcatus (Grouvelle 1898b: 377) [Lado].

sulcifer Sharp 1894b: 464.

terrenus (Pascoe 1863a: 33) [Illestus].

tuberculatus Kraus 1912: 35.

vegrandis Horn 1885: 140.

\section{Lobogestoria Reitter, 1878}

(Fig. 32)

Lobogestoria Reitter 1878a: 31. (1 species)

Currently recognized New World species of Lobogestoria:

*gibbicollis Reitter 1878a: 32.

\section{Lyreus Aubé, 1861}

(Fig. 33)

Lyreus Aubé 1861: 196. (1 species)

Currently recognized New World species of Lyreus: alleni Ivie and Ślipiński 2001: 502.

\section{Megataphrus Casey, 1890}

(Fig. 34)

Megataphrus Casey 1890: 309. (3 species)

Currently recognized species of Megataphrus:

arizonicus Stephan 1989: 27.

chandleri Stephan 1989: 28.

*tenuicornis Casey 1890: 310.

\section{Microprius Fairmaire, 1868}

(Fig. 35)

Microprius Fairmaire 1868: 779. (1 species)

Currently recognized New World species of Microprius:

rufulus (Motschulsky 1863: 502) [Bitoma].

\section{Monoedus Horn, 1882}

(Fig. 36)

Monoedus Horn 1882: 116. (13 spp.) New tribal placement.

Currently recognized species of Monoedus: boliviensis Dajoz 1975: 108.

crispatus (Sharp 1894a: 442) [Adimerus].

crowsoni Dajoz 1975: 105.

cubanensis Dajoz 1975: 107.

grouvellei Dajoz 1975: 108.

*guttatus Horn 1882: 116.

hirtus Dajoz 1975: 107.

horni Grouvelle and Raffray 1908: 42.

lecontei Fleutiaux and Sallé 1889: 391.

obscurus Grouvelle and Raffray 1908: 45.

pubescens Dajoz 1984a: 151.

setosus (Sharp 1894a: 442) [Adimerus].

zonatus Grouvelle and Raffray 1908: 43.

\section{Namunaria Reitter, 1882}

(Fig. 37)

Namunaria Reitter 1882: 114. (2 species)

Currently recognized New World species of Namunaria:

*guttulata (LeConte 1863: 65) [Coxelus].

pacifica (Horn 1878: 569) [Coxelus].

\section{Neotrichus Sharp, 1885}

(Fig. 38)

Neotrichus Sharp 1885: 60. (8 species) Labrotrichus Sharp 1894b: 446. New synonymy.

Currently recognized New World species of Neotrichus:

aberrans (Sharp 1894b: 447). New combination [from Labrotrichus].

bicolor Grouvelle 1896b: 195.

guadalupensis Grouvelle 1902: 758.

insularis Grouvelle 1898a: 38.

latiusculus (Fairmaire 1881: 255) [Bitoma].

nevermanni Hinton 1936: 60.

tuberculatus (Chevrolat 1864: 607) [Plagiope, transferred to Neotrichus by Grouvelle (1898a: 39)].

verrucatus (Hinton 1935b: 206). New combination [from Labrotrichus].

Notocoxelus Ślipiński and Lawrence, 1997 (Fig. 39)

Notocoxelus Ślipiński and Lawrence 1997: 404. (2 species)

Currently recognized New World species of Notocoxelus: 

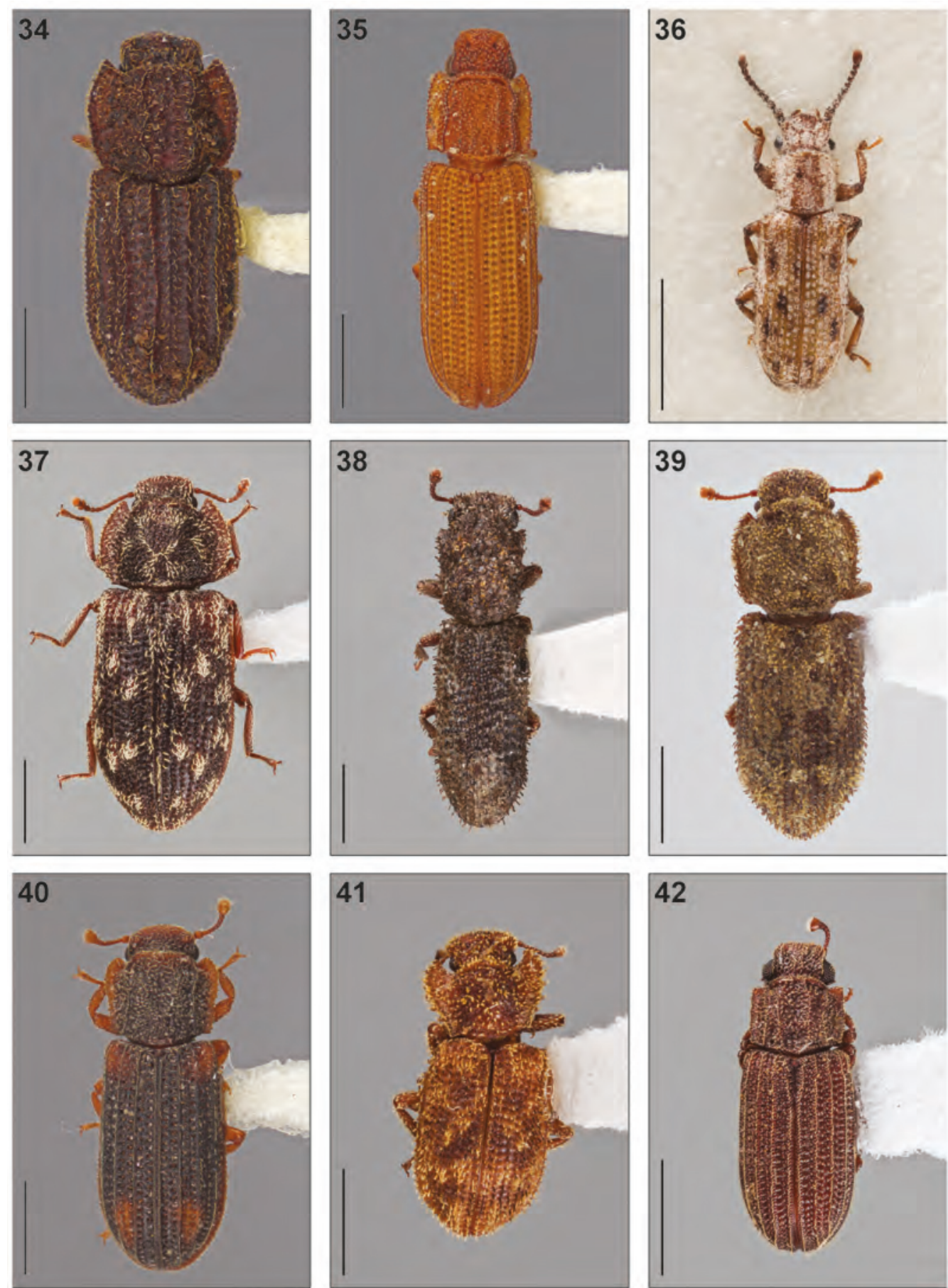

Figs. 34-42. Dorsal habitus of New World colydiine genera, tribe Synchitini. 34) Megataphrus tenuicornis; 35) Microprius rufulus; 36) Monoedus guttatus; 37) Namunaria guttulata; 38) Neotrichus verrucatus; 39) Notocoxelus sp., Chile; 40) Paha laticollis; 41) Paryphus serratus; 42) Paxillobitoma clinei. 
angustatus (Solier 1851: 242). [from Endophloeus and Phloeopsidius Gebien, 1925, placement by Ivie et al. (2016)].

sylvaticus (F. Philippi in Philippi and Philippi 1864: 405). New combination [from Coxelus].

\section{Paha Dajoz, 1984}

(Fig. 40)

Paha Dajoz 1984a: 155. (4 species)

Currently recognized species of Paha:

*guadalupensis Dajoz 1984a: 155.

laticollis (LeConte 1863: 66) [Ditoma].

mexicana (Hinton 1935b: 210). New combination [from Namunaria].

mimetes (Sharp 1894b: 449). New combination [from Synchita].

\section{Paryphus Erichson, 1845}

(Fig. 41)

Paryphus Erichson 1845: 256. (6 species) Hystricones Sharp 1894b: 453. New synonymy.

Currently recognized New World species of Paryphus:

armatus (Sharp 1894b: 453). New combination [from Hystricones].

crassus Grouvelle 1892: 100.

erichsoni Grouvelle 1892: 99.

*lobatus Erichson 1845: 257.

obesus Grouvelle 1892: 101.

serratus Grouvelle 1892: 100.

\section{Paxillobitoma Lord and Ivie, 2016}

(Fig. 42)

Paxillobitoma Lord and Ivie 2016: 744. (1 species)

Currently recognized species of Paxillobitoma:

*clinei Lord and Ivie 2016: 748.

\section{Pharax Pascoe, 1860}

(Fig. 43)

Pharax Pascoe 1860: 113. (1 species)

Currently recognized New World species of Pharax:

*laticollis Pascoe 1860: 114.

\section{Phloeodalis Erichson, 1845}

(Fig. 44)

Phloeodalis Erichson 1845: 257. (2 species)

Currently recognized species of Phloeodalis:

*raucus Pascoe 1863b: 82.

reitteri Grouvelle 1906: 123.

\section{Phloeonemus Erichson, 1845}

(Fig. 45)

Phloeonemus Erichson 1845: 258. (7 species)

Currently recognized species of Phloeonemus:

adhaerens Sharp 1894b: 451.

catenulatus Horn 1878: 568.

*granulatus Erichson 1845: 258.

haroldi Reitter 1878b: 114.

integer Reitter 1877a: 331.

interruptus Reitter 1877a: 330

martorelli Fisher 1943: 131.

\section{Pristoderus Hope, 1840}

(Fig. 46)

Pristoderus Hope 1840: 145. (6 species)

Sparactus Erichson 1845: 256 [Synonymy by Ślipiński and Lawrence (1997)].

Phloeopsidius Gebien 1925: 131 [Synonymy by Ivie et al. (2016)].

Currently recognized New World species of Pristoderus:

brasiliensis (Grouvelle 1896b: 184). New combination [from Ulonotus].

collaris (Kulzer 1966: 62) [Phloeopsidius, placement by Ivie et al. (2016)].

flexuosus (Solier 1851: 241) [Endophloeus, placement by Ivie et al. (2016)].

porteri (Brèthes 1925: 198). New combination [from Endophloeus].

regularis (Kulzer 1966: 61) [Phloeopsidius, placement by Ivie et al. (2016)].

sharpi (Reitter 1877a: 323). New combination [from Endophloeus].

\section{Pseudocorticus Hinton, 1935}

(Fig. 47)

Pseudocorticus Hinton 1935b: 212. (1 species)

Currently recognized species of Pseudocorticus:

*blairi Hinton 1935b: 212.

Rapthius Lord and Ivie, 2016

(Fig. 48)

Rapthius Lord and Ivie 2016: 748. (1 species)

Currently recognized New World species of Rapthius:

*peruvianus (Franz 1969: 144) (from Tarphius).

\section{Reylus Ivie, Lord, Foley, and Ślipiński}

(Fig. 49)

Reylus Ivie, Lord, Foley, and Ślipiński. New replacement name. (1 species) 

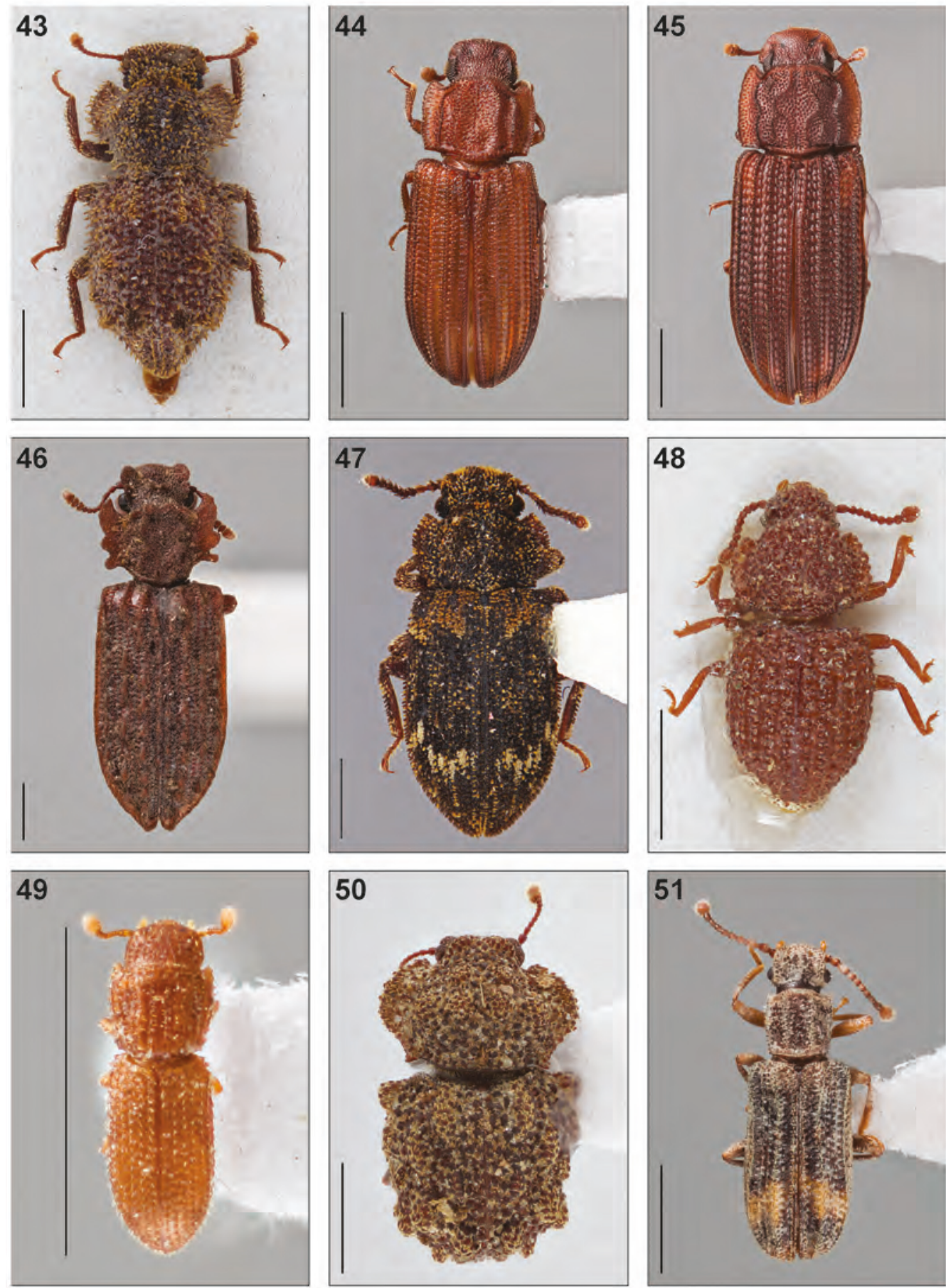

Figs. 43-51. Dorsal habitus of New World colydiine genera, tribe Synchitini. 43) Pharax laticollis; 44) Phloeodalis raucus; 45) Phloeonemus integer; 46) Pristoderus regularis; 47) Pseudocorticus blairi; 48) Rapthius peruvianus; 49) Reylus chilensis; 50) Slipinskius chilensis; 51) Stenomonoedus garleppi. 
Erylus Dajoz 1969: 232 [not Erylus Gray, 1867 (Porifera)].

Currently recognized species of Reylus:

*chilensis (Dajoz 1969: 232). New combination [from Erylus].

\section{Slipinskius Lord and Ivie, 2016}

(Fig. 50)

Slipinskius Lord and Ivie 2016: 750. (1 species)

Currently recognized New World species of Slipinskius:

*chilensis (Franz 1969: 143) [Tarphius].

\section{Stenomonoedus Heinze, 1954}

(Fig. 51)

Stenomonoedus Heinze 1954: 163. (1 species). New tribal placement.

Currently recognized species of Stenomonoedus: *garleppi Heinze 1954: 164.

\section{Synchita Hellwig in Schneider, 1792}

(Fig. 52)

Synchita Hellwig in Schneider 1792: 401. (10 species)

Microsicus Sharp 1894b: 456. New synonymy.

Currently recognized New World species of Synchita:

dubia Hinton 1936: 58.

exilis (Grouvelle 1898b: 38). New combination [from Catolaemus].

fuliginosa Melsheimer 1846: 111.

Synchita nigripennis LeConte 1863: 67.

grouvellei Ivie, Lord, Foley, and Ślipiński (replacement name for Microsicus minimus Grouvelle, 1898, junior secondary homonym of Cicones minimus Sharp, 1885). New replacement name.

lecontei Ivie, Lord, Foley, and Ślipiński (replacement name for Synchita variegata LeConte, 1858: 63, junior secondary homonym of Cicones variegatus Hellwig in Schneider 1792: 403). New replacement name.

multimaculata (Grouvelle 1902: 759). New combination [from Catolaemus].

parvula Guérin-Méneville 1844: 189. Returned to previous generic assignment.

pauxilla (Pascoe 1863b: 81). New combination [from Bitoma].

obscura Horn 1885: 140.

striatopunctata Guérin-Méneville 1844: 190.
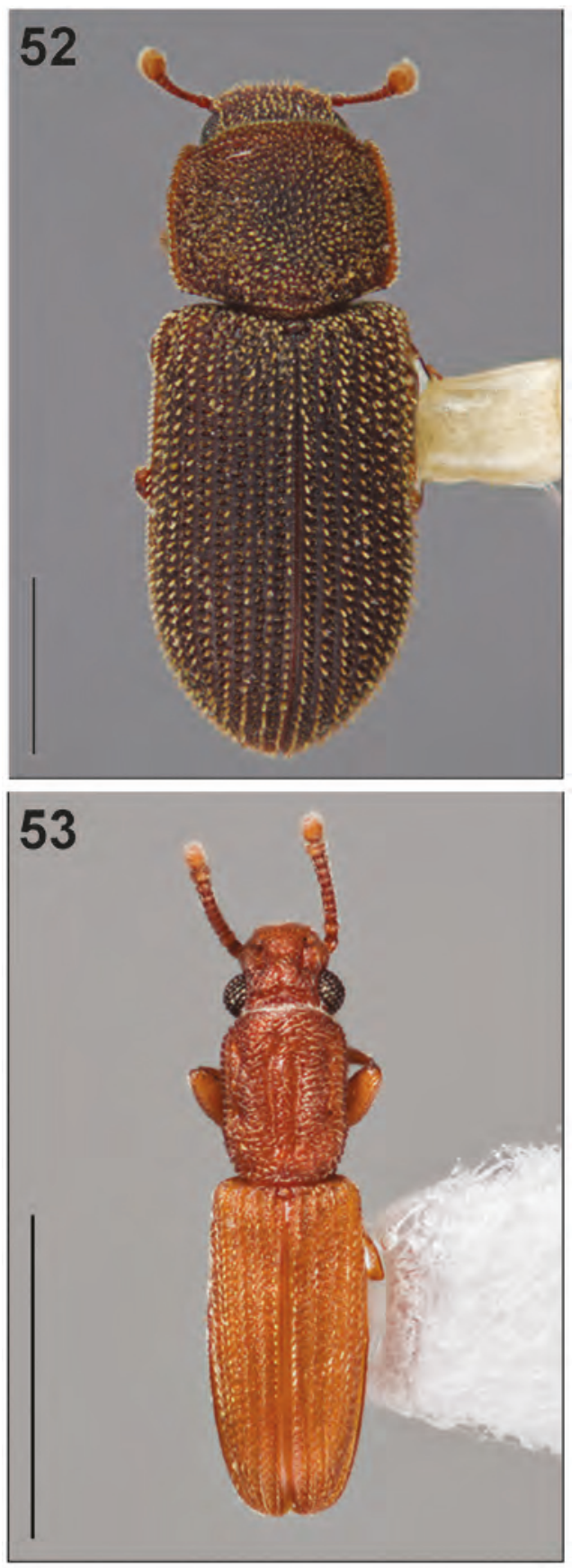

Figs. 52-53. Dorsal habitus of New World colydiine genera, tribe Synchitini and incertae sedis. 52) Synchita fuliginosa; 53) Phreatus rigidus. 


\section{INCERTAE SEDIS}

(1 genus, 2 species)

\section{Phreatus Pascoe, 1863}

(Fig. 53)

Phreatus Pascoe 1863b: 90. (2 species)

Currently recognized species of Phreatus:

immsi Hinton 1936: 79.

*rigidus Pascoe 1863b: 90.

\section{ACKnOwledgments}

Over the last 30 years, tens of thousands of specimens have been examined, borrowed, lent, given, received, exchanged, bought, sold, photographed, and shared by all of us interacting with a number of curators, colleagues, collaborators, friends, and others too numerous to include by name here. You know who you are, and we thank you. Collaboration on this project between MAI and SAS was discussed in 1984 under an NSF Dissertation Improvement Grant and became a real project with support from the Polska Akademia Nauk/US National Academy Exchange in 1988. The work was also partially supported by USDA-APHIS-PPQ-CPHST Farm Bill funding to NPL, E. H. Nearns, and K. B. Miller (University of New Mexico, 10-8100-1439-CA). Contiuous encouragement, support, and the occasional push has been provided over this entire time frame by LaDonna Ivie. Several people provided specific assistance to the project and deserve special thanks. Maxwell V. L. Barclay (The Natural History Museum) provided nomenclatural advice. Thierry Deuve (Muséum national d'Histoire naturelle) interceded on our behalf with Roger Dajoz (retired), who gave permission to propose a replacement name for one of his preoccupied names. Crystal Maier (Field Museum of Natural History) loaned last minute specimens. Charles Hart (Montana State University) and Gavin Martin (Brigham Young University) did testing of the key and manuscript review. Matthew L. Gimmel (Santa Barbara Museum of Natural History) and Rudolf Schuh (Katzelsdorf, Austria) greatly improved an earlier version of the manuscript with detailed and thoughtful reviews. Vinicius Ferreira and Frank Etzler (Montana State University) provided help and interesting discussions. Dione Seripierri and Gustavo Rizzi (Museu de Zoologia da Universidade de São Paulo Library), helped date the Bondar references. Keita Matsumoto helped with translation of Japanese references. KlausDieter Klass (Staatliches Museum für Tierkunde, Dresden) provided information on missing types. NPL would like to thank K. B. Miller (University of New Mexico), S. Bybee (Brigham Young University), and R. A. B. Leschen (Landcare Research, Auckland, NZ) for supporting his study of Zopheridae. This is a contribution of the Montana Agricultural Experiment Station.

\section{References Cited}

Aoki, J. 2011. Unrecorded species and description of new genus, Microsicus, from Japan. Kanagawa Chûhô (173): 1-9. [In Japanese]

Aoki, J. 2012a. Cylindrical Bark Beetles of Japan. Families Bothrideridae and Zopheridae. RopponAshi Entomological Books, Tokyo, Japan.

Aoki, J. 2012b. A new species of the genus Microsicus from Ishigaki Island, South Japan (Coleoptera, Zopheridae, Colydiinae). Elytra 2: 217-219.

Aubé, C. 1861. Description six espéces nouvelles de coléoptères d'Europe. Dont deu appurtenant a deux genres nouveaux et aveugles. Annales de la Société entomologique de France (Series 4)1: 195-199.

Arrow, G. J. 1909. Systematic notes on Coleoptera of the clavicorn families. The Annals and Magazine of Natural History 4(8): 190-196.

Arrow, G. J. 1927. Clavicornia and Lamellicornia [pp. 35-66]. In: Insects of Samoa and other Samoan Terrestrial Arthropoda. Part IV. Coleoptera. Fasc. 1. British Museum (Natural History), London, UK.

Blackwelder, R. E. 1945. Checklist of the coleopterous insects of Mexico, Central America, the West Indies, and South America, part 3. Bulletin of the United States National Museum 185: 343-550.

Blaisdell, F. E. 1925. Expedition to Guadalupe Island, Mexico, in 1922. Proceedings of the California Academy of Sciences 14(4): 321-343.

Blatchley, W. S. 1910. An illustrated descriptive catalogue of the Coleoptera or beetles (exclusive of the Rhynchophora) known to occur in Indiana. Indiana Department of Geology and Natural Resources Bulletin 1: 1-1386.

Bondar, G. 1940a. Insetos nocivos e moléstias do Coueiro (Cocos nucifera) no Brasil. Boletím do Instituto Central de Fomento Economico da Bahia 8: 1-160. [Published 25 March 1940]

Bondar, G. 1940b. Notas entomológicas da Bahia. VI. Revista de Entomologia Rio de Janeiro 11: 842-861. [Published 3 December 1940]

Brèthes, J. 1925. Coléoptères et diptères chiliens. Revista Chilena de Historia Natural 29: 198-208.

Burmeister, H. C. C. 1840. Genera quaedam insectorum. Berolini 1(5): 10 pp., pls. 21-25.

Casey, T. L. 1890. Coleopterological notices. II. Annales of the New York Academy of Sciences 5: 307-504.

Champion, G. C. 1913. Notes on various Central American Coleoptera, with descriptions of new genera and species. Transactions of the Entomological Society of London [1913]: 58-169, pls. III-IV.

Chevrolat, L. A. A. 1864. Coléoptères de l'Ile de Cuba. (Suite) Notes, synonymies et descriptions d'espèces nouvelles. Quatrième mémoire. Famille des 
histériens, phalaircrides, nitidulaires, trogositaires, colydiens, rhysodides, cucujipes, mycétophagides, dermestins, byrrhiens et chélonariides. Annales de la Société Entomologique de France, 1863 (1864), ser.4, 3: 589-620. [23 March 1864].

Cossmann, M. 1888. Catalogue illustré des coquilles fossiles de l'Eocène des environs de Paris. Annales de la Société royale malacologique de Belgique 23: 1-328, plates 1-12.

Crotch, G. R. 1874. Descriptions of new species of Coleoptera from the Pacific Coast of the United States. Transactions of the American Entomological Society 5: 73-80.

Dajoz, R. 1969. Nouveaux Colydiidae anophthalmes du Chili [Col.]. Bulletin de la Société entomologique de France 74: 230-234.

Dajoz, R. 1975. Notes sur le genre Monoedus Horn (Coléoptères, Colydiidae) et description d'especes nouvelles. Bulletin Mensuel de la Société Linnéenne de Lyon 44: 103-110.

Dajoz, R. 1977. Coléoptères Colydiidae et Anommatidae Paléarctiques. Faune de l'Europe et du Bassin Mediterraneen 8: 1-275.

Dajoz, R. 1980a. Insectes Coléoptères: Colydiidae et Cerylonidae. Faune de Madagascar. Paris, 54: $1-256$.

Dajoz, R. 1980b. Les coléoptères Colydiidae de la region néotropicale I. La tribu des Colydiini. Annales de la Société Entomologique de France 16(3): 325-343.

Dajoz, R. 1984a. Note sur quatre genres de Coléoptères Colydiidae: Nematidium Erichson, Monoedus Horn, Lobogestoria Reitter et Paha n. gen. Bulletin Mensuel de la Société Linnéenne de Lyon 53(4): 145-157.

Dajoz, R. 1984b. Étude des genres Pseudaulonium Reitter et Anarmostes Pascoe, de la région néotropicale (Coleoptera, Colydiidae). Nouvelle Revue d'Entomologie 1(2): 151-164.

Dejean, P. F. M. A. 1821. Catalogue de la Collection de Coléoptères de M. le Baron Dejean. Paris, France.

Doyen, J. T. 1966. The skeletal anatomy of Tenebrio molitor (Coleoptera: Tenebrionidae). Miscellaneous Publications of the Entomological Society of America 5: 103-150.

Doyen, J. T., and J. F. Lawrence. 1979. Relationships and higher classification of some Tenebrionidae and Zopheridae (Coleoptera). Systematic Entomology 4: 333-377.

Erichson, W. F. 1845. Naturgeschichte der Insecten Deutschlands. Erste Abtheilung, Coleoptera 3: (1-2) 1-320.

Fabricius, J. C. 1792. Entomologia Systematica emendata et aucta. Hafniae. Tom I (1): XX+ 333 pp.;(2): 538 pp.

Fabricius, J. C. 1775. Systema Entomologiae, sistens insectorum classes, ordines, genera, species, adiectis synonymis, locis, descriptionibus, observationibus. Officina Libraria Kortii, Flensburgi et Lipsiae.

Fabricius, J. C. 1801. Systema Eleutheratorum secundum ordines, genera, species: adiectis synonymis, locis, observationibus, descriptionibus. 2. Bibliopolii Academici Novi, Kiliae.
Fairmaire, L. 1850. Essai sur les Coléoptères de la Polynésie (suite). Revue et Magazin de Zoologie Pure et Appliquee 2(2): 50-64, 115-122, 181-185.

Fairmaire, L. 1868. Notes sur les Coléoptères recueillis par Charles Coquerel à Madagascar et sur les côtes d'Afrique. Annales de la Société Entomologique de France (Series 4) 8: 753-820.

Fairmaire, L. 1881. Essai sur les coléoptères des iles Viti (Fidgi). Annales de la Société Entomologique de France (Series 6)1: 243-318, 461-492.

Ferreira, V. S., and G. I. Marques dos Santos. 2015. Colydodes flavisetis sp. nov. (Coleoptera, Zopheridae, Colydiinae), new species from southeastern Brazil with an updated key to the species of the genus. Zootaxa 3981: 437-443.

Fisher, W. S. 1943. A new species of Phloeonemus from Puerto Rico (Coleoptera: Colydiidae). Journal of Agriculture of the University of Puerto Rico 27: 131-132.

Fleutiaux, E., and A. Sallé. 1889. Liste des coléoptères de la Guadeloupe et descriptions d'espèces nouvelles. Annales de la Société Entomologique de France (Series 6)9: 351-484.

Foley, I. A., and M. A. Ivie. 2008. A revision of the genus Phellopsis LeConte (Coleoptera: Zopheridae). Zootaxa 1689: 1-28.

Franz, H. 1969. Zwei Vertreter der Gattung Tarphius Erichson. Entomologische Blätter 65: 143-145.

Gebien, H. 1925. Die Tenebrioniden (Coleoptera) des Indomalayischen Gebietes, unter Beruecksichtigung der benachbarten Faunen, IV/ Die Gattungen Phloeopsidius, Dysantes, Basanus, und Diaperis. Philippine Journal of Science 27: 131-157.

Gegenbaur, C. 1856. Versuch eines Systemes der Medusen, mit Beschreibung neuer oder wenig gekannter Formen; zugleich ein Beitrag zur Kenntniss der Fauna des Mittelmeeres. Zeitschrift für wissenschaftliche Zoologie 8 no. 2, 202-273. [Frontpiece says 1847, but the table of contents says that number 2 was "Ausgegeben" (distributed, sent out) on 12 July 1856$]$

Gray, J. E. 1867. Notes on the arrangement of sponges, with description of some new genera. Proceedings of the Zoological Society of London 1867(2): $492-558$

Grouvelle, A. H. 1892. Voyage de M. E. Simon au Venezuela (Décembre 1887-Avril 1888). $19^{\mathrm{e}}$ mémoire. Coléoptères. Colydiides. Annales de la Société Entomologique de France (Series 6) 61: 99-102.

Grouvelle, A. H. 1896a. Description de Clavicornes d'Afrique et de Madagascar. Annales de la Société Entomologique de France 65: 71-94.

Grouvelle, A. H. 1896b. Nitidulides, Colydiides, Cucujides et Parnides récoltés par M.E. Gounelle au Brésil et autres Clavicornes nouveau d'Amérique. Annales de la Société Entomologique de France 65: 177-216.

Grouvelle, A. H. 1898a. Clavicornes de Grenada et de St. Vincent (Antilles) récoltés par M.H.H. Smith, et appurtenant au Musée de Cambridge. Notes from the Leyden Museum, 20: 35-48. 
Grouvelle, A. H. 1898b. Clavicornes nouveaux d'Amérique. $2^{\mathrm{e}}$ mémoire. Annales de la Société Entomologique de France 67: 344-381.

Grouvelle, A. H. 1902. Supplément a la liste des coléoptères de la Guadeloupe de MM Fleutiaux et Sallé. Annales de la Société Entomologique de France 71: 756-769.

Grouvelle, A. H. 1905. Nitidulides, colydiides, cucujides et mycetophagides de la Guinée Espangnole. Memorias de la Sociedad Española de Historia Natural 1(14): 241-260.

Grouvelle, A. H. 1906. Nitidulides, colydiides, cucujides, monotomides et helmides nouveaux. Revue d'Entomologie 25: 113-120.

Grouvelle, A. H. 1914. Mission géodésique de l'Equateur. Insectes recueillis par M. le Dr. Rivet. Coléoptères clavicorns. Bulletin du Muséum National d'Histoire Naturelle 20: 43-56.

Grouvelle, A. H. 1918. Coleoptera of the families Ostomidae, Monotomidae, Colydiidae und Notiophygidae from the Seychelles and Aldabra Islands. Transactions of the Entomological Society of London 1918: 1-57, pls. I, II.

Grouvelle, A. H. 1919. Die in vorstehender Liste erwähnten neuen Arten. Mitteilungen aus dem Zoologischen Museum in Berlin 9: 204-213.

Grouvelle, A. H., and A. Raffray. 1908. Supplément a la liste des Coléoptères de la Guadeloupe de MM Fleutiaux et Sallé. Annales de la Société Entomologique de France 77: 33-64.

Grouvelle, A. H., and A. Raffray. 1913. Supplément a la liste des Coléoptères de la Guadeloupe. Annales de la Société Entomologique de France 81: 289-312 [1912].

Guérin-Méneville, F. E. 1829-1844. Iconographie $\mathrm{du}$ règne animal de $\mathrm{G}$. Cuvier, vol. 7, insectes, 1829-1838 (1844), 576 p., 104 pls. Paris, France.

Heinze, E. 1954. Colydiidae (Col.). Beiträge zur Fauna Perus 4: 156-169.

Hellwig, J. C. L. in Schneider, D. H. 1792. Dritte Nachricht von neuen Gattungen im entomologischen System. Neuestes Magazin für die Liebhaber der Entomologie, herausgegeben von David Heinrich Schneider, Königl Schwedischem Tribunals Regierungs und Hosgerichts Uddofaten in Stralsund. Stralsund I (4): 385-408.

Herbst, J. F. W. 1793. Natursystem aller bekannten inund ausländischen Insekten, als eine Fortsetzung der von Büffonschen Naturgeschichte. Der Käfer fünfter Theil. XVI+392 pp, pls. 44-59 + J-N. Pauli, Berlin, Germany.

Hetschko, A. 1930. Coleopterorum Catalogus, pars 107, Colydiidae, pp. 1-124.

Hinton, H. E. 1935a. Notes of the American species of Colydodes (Coleoptera, Colydiidae). Entomologist's Monthly Magazine 71: 227-232.

Hinton, H. E. 1935b. New genera and species of Neotropical Colydiidae, with notes on others (Col.). Revista de Entomología 5: 202-215.

Hinton, H. E. 1936. Miscellaneous studies in the Neotropical Colydiidae (Col.). Revista de Entomologia 6(1): 47-97.

Hope, F. W. 1840. The Coleopterist's manual, part the third, containing various families, genera, and species, recorded by Linneus and Fabricius. Also descriptions of newly discovered and unpublished insects. J. C. Bridgewater, London, UK.

Horn, G. H. 1867. On Rhagodera tuberculata, Mannerheim. Proceedings of the Entomological Society of Philadelphia 7: 294-296.

Horn, G. H. 1878. Synopsis of the Colydiidae of the United States. Proceedings of the American Philosophical Society 17: 555-592.

Horn, G. H. 1882. Notes on some little known genera and species of Coleoptera. Transactions of the American Entomological Society 10: 113-126.

Horn, G. H. 1885. Contributions to the coleopterology of the United States. No. 4. Transactions of the American Entomological Society 12: 128-162.

Hunt, T., J. Bergsten, Z. Levkanicova, A. Papadopoulou, O. St. John, R. Wild, P. M. Hammond, D. Ahrens, M. Balke, M. S. Caterino, J. Gómez-Zurita, I. Ribera, T. G. Barraclough, M. Bocakova, L. Bocak, and A. P. Vogler. 2007. A comprehensive phylogeny of beetles reveals the evolutionary origins of a superradiation. Science 318: 1913-1916.

ICZN (International Commission on Zoological Nomenclature). 1999. International Code of Zoological Nomenclature, $4^{\text {th }}$ Edition. International Trust for Zoological Nomenclature, London, UK.

Ivie, M. A. 2002. Chapter 103. Colydiidae Erichson 1845 [pp. 445-453]. In: American Beetles. Vol. 2. Polyphaga: Scarabaeoidea through Curculionoidea (R. H. Arnett, Jr., M. C. Thomas, P. E. Skelley, and J. H. Frank, editors). CRC Press, Boca Raton FL.

Ivie, M. A. 2010. Additions and corrections to Borowski and Węgrzynowicz's world catalogue of Bostrichidae (Coleoptera). Zootaxa 2498: 28-46.

Ivie, M. A., N. P. Lord, and M. Elgueta. 2016. Resolving a branching taxonomy conundrum-can one species be in two places at one time under the same name (Zopheridae: Colydiinae and Tenebrionidae)? The Coleopterists Bulletin 70: 105-110.

Ivie, M. A., and S. A. Ślipiński. 1989. Review of the genus Colydodes Motschulsky (Coleoptera: Colydiidae). The Coleopterists Bulletin 43(3): 237-251.

Ivie, M. A., and S. A. Ślipiński. 1990. Catalog of the genera of World Colydiidae (Coleoptera). Annales Zoologici 43(supplement 1): 1-32.

Ivie, M. A., and S. A. Ślipiński. 2001. A new species of Lyreus Aubé from Alabama, first report of the genus from the New World (Zopheridae: Colydiinae: Synchitini). The Coleopterists Bulletin 55: 501-505.

Ivie, M. A., S. A. Ślipiński, and P. Wegrzynowicz. 2001. New records and synonyms in the Colydiinae and Pycnomerini (Coleoptera: Zopheridae). Insecta Mundi 15: 185-188.

Kingsolver, J. M., K. Stephan, and J. C. Moser. 2006. A new species of Lasconotus (Coleoptera: Colydiidae) from Arizona and South Dakota, U.S.A. Entomological News 117: 53-56. 
Kirsch, T. 1865. Beiträge zur Käferfauna von Bogota. Berliner Entomologische Zeitschrift 9: 40-104, pl. III.

Kraus, E. J. 1912. A revision of the genus Lasconotus Er. (Coleoptera; Colydiidae). Proceedings of the Entomological Society of Washington 14: $25-44$.

Krinsky, W. L. 2015. A new species of Rhagodera Mannerheim (Coleoptera: Zopheridae: Colydiinae) from San Clemente Island, California. The Coleopterists Bulletin 69(2): 293-296.

Kulzer, H. 1966. Neue Tenebrioniden aus Süd-Amerkia (Col.). Entomologische Arbeiten aus dem Museum G. Frey, Tutzing 17: 48-69.

Lacordaire, J. T. 1854. Histoire naturelle des Insectes. Genera des Coléoptères ou esposé méthodique de tous les genres proposés jusqu'ci dans cetordre d'insectes, Paris 2: 1-548.

Lawrence, J. F. 1991. Colydiidae (Tenebrionoidea) [pp. 512-514]. In: Immature Insects, Volume 2 (F. W. Stehr, editor). Kendall Hunt Publishing Co., Dubuque, IA.

Lawrence, J. F., R. G. Beutel, R. A. B. Leschen, and A. Ślipiński. 2010. 2. Glossary of morphological terms [pp. 9-20]. In: Handbuch der Zoologie/ Handbook of Zoology. Band/Volume IV Arthropoda: Insecta Teilband/Part 38. Coleoptera, Beetles. Volume 2. Morphology and Systematics (Polyphaga partim). (R. A. B. Leschen, R. G. Beutel, and J. F. Lawrence, editors). W. DeGruyter, Berlin, Germany.

Lawrence, J. F., and E. B. Britton. 1991. Coleoptera (Beetles) [pp. 543-683]. In: The Insects of Australia. $2^{\text {nd }}$ Edition. Volume 2. (CSIRO, editors). Melbourne University Press, Melbourne, Australia.

Lawrence, J. F., A. M. Hastings, M. J. Dallwitz, T. A. Paine, and E. J. Zurcher. 1999. Beetles of the World: A Key and Information System for Families and Subfamilies. CDROM, Version 1.0 for MS-Windows. CSIRO Publishing, Melbourne, Victoria, Australia.

Lawrence, J. F., S. A. Ślipiński, A. E. Seago, M. K. Thayer, A. F. Newton, and A. E. Marvaldi. 2011. Phylogeny of the Coleoptera based on morphological characters of adults and larvae. Annals of Zoology (Warszawa) 61: 1-217.

LeConte, J. L. 1858. Descriptions of new species of Coleoptera, chiefly collected by the United States and Mexican Boundary Commission, under Major W.H. Emory, U.S.A. Proceedings of the Academy of Natural Sciences of Philadelphia [vol. 10]1858: 59-89.

LeConte, J. L. 1859a. Catalogue of the Coleoptera of Fort Tejon, California. Proceedings of the Academy of Natural Sciences of Philadelphia 11: 69-90.

LeConte, J. L. 1859b. Additions to the coleopterous fauna of northern California and Oregon. Proceedings of the Academy of Natural Sciences of Philadelphia 11: 281-292.

LeConte, J. L. 1863. New species of North American Coleoptera. I. Smithsonian Miscellaneous Collections No. 167: 1-92.
LeConte, J. L. 1866. Additions to the coleopterous fauna of the United States. No. 1. Proceedings of the Academy of Natural Sciences of Philadelphia 1866: 361-394.

Lord, N. P., and M. A. Ivie. 2016. Several new genera and species of New World Synchitini (Coleoptera: Zopheridae: Colydiinae). The Coleopterists Bulletin 70(4): 715-753.

Lord, N. P., and R. A. B. Leschen. 2014. Catalog and type designations of the New Zealand Zopheridae. Zootaxa 3809(1): 1-127.

Lord, N. P., E. H. Nearns, and K. B. Miller. 2011. Ironclad ID: Tool for Diagnosing Ironclad and Cylindrical Bark Beetles (Coleoptera: Zopheridae) of North America north of Mexico. The University of New Mexico and Center for Plant Health Science and Technology, USDA, APHIS, PPQ. coleopterasystematics.com/ ironcladid/IroncladID-about.html (accessed 1 June 2016).

Lyal, C. H. C. 2011. The dating of the Biologia Centrali-Americana. Zoological Bibliography 1(2): 67-100.

Mannerheim, C. G. 1843. Beitrag zur Kaefer-Fauna der Aleutischen Inseln, der Insel Sitkha und Neu-Californiens. Bulletin de la Société Impériale des Naturalistes de Moscou 16(11): 175-314.

McKenna, D. D., A. L. Wild, K. Kanda, C. L. Bellamy, R. G. Beutel, M. S. Caterino, C. W. Farnum, D. C. Hawks, M. A. Ivie, M. L. Jameson, R. A. B. Leschen, A. E. Marvaldi, J. V. McHugh, A. F. Newton, J. A. Robertson, M. K. Thayer, M. F. Whiting, J. F. Lawrence, A. Ślipiński, D. R. Maddison, and B. D. Farrell. 2015. The Beetle Tree of Life reveals Coleoptera survived end-Permian mass extinction to diversify during the Cretaceous terrestrial revolution. Systematic Entomology 40: 835-880. DOI: $10.1111 /$ syen.12132.

Melsheimer, F. E. 1846. Descriptions of new species of Coleoptera of the United States. Proceedings of the Academy of Natural Sciences of Philadelphia 2: $98-118$

Motschulsky, V. 1855. Voyages. Lettre de M. de Motschulsky à M. Ménéreiés. No. 2, À bord du bateau à vapeur United States, 20 Mars 1854. Études Entomologiques, pt. 4: 8-25.

Motschulsky, V. 1863. Essai d'un catalogue des insectes de l'Île Ceylan. Premier partie. Bulletin de la Sóciété Impériale des Naturalistes de Moscou 36: 421-532.

Nakane, T. 1967. New and little-known Coleoptera from Japan and its adjacent area. XXVI. Fragmenta Coleopterologica 19: 73-76.

Nevermann, W. H. F. 1930. Zwei neue Colydiiden aus Costa Rica (Col.). Entomologische Blätter 26: $110-114$.

Pascoe, F. P. 1860. Notices of new or little-known genera and species of Coleoptera, Part II. Journal of Entomology 1: 98-132, pls. V-VIII.

Pascoe, F. P. 1863a. Notices of new or little-known genera and species of Coleoptera, Part IV. Journal of Entomology 2: 26-56, pls. II-III. 
Pascoe, F. P. 1863b. List of the Colydiidae collected in the Amazons Valley by H.W. Bates, Esp., and descriptions of new species. Journal of Entomology 2: 79-99, pl. V.

Pascoe, F. P. 1866. Notices of new or little-known genera and species of Coleoptera. The Journal of Entomology 2: 443-492, pls. XVIII-XIX.

Pic, M. 1922. Notes diverses, descriptions et diagnoses (Suite). L'Échange, Revue Linnéenne 38: 21-23.

Philippi, R. A., and F. H. E. Philippi. 1864. Beschreibung einiger neuen Chilenischen Käfer. Stettiner Entomologische Zeitung 25: 313-406.

Pope, R. D. 1954. On a collection of Colydiidae (Coleoptera) from Angola. Publiçaóes Culturais da Companhia de Diamantes de Angola 23: 109-118.

Pope, R. D. 1961. Colydiidae (Coleoptera Clavicornia). Exploration du Parc National de la Garamba. Fascicule 25. Mission H. de Saeger. Bruxelles, Belgium.

Reitter, E. 1876. Systematische Eintheilung der Trogositidae (Familia coleopterorum). Verhandlungen des Naturforschenden Vereines in Brün, vol. 14, Abhandlungen, pp. 3-69. [1875].

Reitter, E. 1877a. Beitrag zur Kenntniss der Colydier. Stettiner Entomologische Zeitung 38(1-3): 323-356

Reitter, E. 1877b. Neue Arten aus den Familien der Cucujidae, Nitidulidae, Colydiidae und Cryptophagidae. Mittheilungen des Münchener Entomologischen Vereins 1: 22-28.

Reitter, E. 1877c. Beiträge zur Kenntniss aussereuropäischer Coleopteren. Mittheilungen des Münchener Entomologischen Vereins 1: $126-140$.

Reitter, E. 1878a. Lobogestoria nov. gen. Latridarum. Deutsche Entomologische Zeitschrift 22(1): 31-32.

Reitter, E. 1878b. Neue Colydiidae des Berliner Museums. Deutsche Entomologische Zeitschrift 22(1): 113-125.

Reitter, E. 1882. Bestimmungs-Tabellen der europäischen Coleopteren. VI. Enthaltend die Familien Colydiidae, Rhysodidae, Trogositidae. Verhandlungen des Naturforschenden Vereines in Brünn 20: 113-149.

Say, T. 1826. Descriptions of new species of coleopterous insects, inhabiting the United States (continued). Journal of the Academy of Natural Sciences of Philadelphia 5(pt. 2): 237-284, 293-304 [continued from 1825].

Sasaji, H. 1971. Description of a new Cicones-species in Japan (Coleoptera: Colydiidae). The Life Study (Fukui) 15: 43-45.

Schaeffer, C. 1907. A few new Coleoptera of the genus Bitoma, with notes on other Colydiidae. Proceedings of the Entomological Society of Washington 8: 136-141.

Sharp, D. 1879. On some Coleoptera from the Hawaiian Islands. Transactions of the Entomological Society of London 1879: 77-105.

Sharp, D. 1885. On the Colydiidae collected by Mr. G. Lewis in Japan. The Journal of the Linnean Society, Zoology 19: 58-84, pl. III. [1886]
Sharp, D. 1894a. Adimeridae [pp. 441-443, plate 14]. In: Biologia Centrali-Americana. Insecta. Coleoptera. Volume 2, part 1. (F. Godman, and O. Salvin, editors.). Taylor \& Francis, London, UK.

Sharp, D. 1894b. Colydiidae [pp. 443-488, plates 1415]. In: Biologia Centrali-Americana. Insecta. Coleoptera. Volume 2, part 1 (F. Godman, and O. Salvin, editors). Taylor and Francis, London, UK.

Ślipiński, S. A. 1985. Studies on the African Colydiidae (Coleoptera). Part III. Genus Bitoma Herbst. Polskie Pismo Entomologiczne 55: 477-489.

Ślipiński, S. A., and B. Burakowski. 1988. A review of the genus Rhopalocerus W. Redtenbacher of the World (Coleoptera, Colydiidae). Annales Zoologici (Warszawa) 42(2): 75-118.

Ślipiński, S. A., and J. F. Lawrence. 1997. Genera of Colydiinae (Coleoptera: Zopheridae) of the Australo-Pacific Region. Annales Zoologici (Warszawa) 47(3/4): 341-440.

Ślipiński, S. A., and J. F. Lawrence. 1999. Phylogeny and classification of Zopheridae sensu novo (Coleoptera: Tenebrionoidea) with a review of the genera of Zopherinae (excluding Monommatini). Annales Zoologici (Warszawa) 49: 1-53.

Ślipiński, S. A., and J. F. Lawrence. 2010. Zopheridae Solier, 1834. In: Handbuch der Zoologie/Handbook of Zoology. Band/Volume IV Arthropoda: Insecta Teilband/Part 38. Coleoptera, Beetles. Volume 2. Morphology and Systematics (Polyphaga partim) (R. A. B. Leschen, R. G. Beutel, and J. F. Lawrence, editors). W. DeGruyter, Berlin,Germany.

Ślipiński, S. A., and R. Schuh. 2008. Zopheridae. In Catalogue of Palaearctic Coleoptera Vol. 5 (I. Löbl, and A. Smetana, editors). Apollo Books, Stenstrup, Denmark.

Solier, A. 1851. Orden III. Coleópteros. In: Historia Fisica y Politica de Chile segun documentos adquiridos en esta republica durante doce anos de residencia en ella (C. Gay, editor). 5: 1-285 [Also appearing as Fauna Chilena. Insectos. Coleopteros.]

Stephan, K. 1989. The Bothrideridae and Colydiidae of America north of Mexico (Coleoptera: Clavicornia and Heteromera). Occasional Papers of the Florida State Collection of Arthropods 6: XII-65.

Thomson, J. in Lacordaire, J. T. 1854. Histoire naturelle des Insectes. Genera des Coléoptères ou esposé méthodique de tous les genres proposés jusqu'ci dans cetordre d'insectes, Paris 2: 1-548.

Thomson, J. 1857. Description d'un Colydiide. Archives Entomologiques 1: 422-424.

Wankowiez, J. 1867. Descriptions de trois coléoptères nouveaux trouves en Lithuanie. Annales de la Société Entomologique de France (Series 4) 7: 249-254.

Wegrzynowicz, P. 1999. A revision of the genus Colydium Fabricius, 1792 (Coleoptera: Zopheridae: Colydiinae). Annales Zoologici 49(3): 265-328.

Wollaston, T. V. 1867. Coleoptera Hesperidum, being an Enumeration of the Coleopterous Insects of 
the Cape Verde Archipelago. John van Voorst, London, UK.

Zayas, F. de. 1988. Entomofauna Cubana. Orden Coleoptera. Separata. Descripcion de nuevas especies. Editorial Cientifico-Tecnica. La Habaña, Cuba.

Zimmermann, C. C. A. 1869. Synonymical notes on Coleoptera of the United States - with descriptions of new species, from the MSS of the late
Dr. C. Zimmermann (edited by J. L. LeConte). Transactions of the American Entomological Society 2: 243-259.

(Received 7 June 2016; accepted 2 October 2016. Publication date 18 December 2016.) 